\title{
Organic matter and benthic metabolism in euphotic sediments along shallow sub-tropical estuaries, northern New South Wales, Australia
}

\author{
Angus J. P. Ferguson*, Bradley D. Eyre, Jennita M. Gay \\ Centre for Coastal Management, Southern Cross University, PO Box 157, East Lismore 2480, New South Wales, Australia
}

\begin{abstract}
Sediment organic matter (OM), chloropigments and benthic metabolism (oxygen, carbon dioxide and alkalinity fluxes) were investigated along 3 sub-tropical Australian estuaries during different seasons. Significant rates of benthic productivity occurred throughout the year in the study estuaries, especially in the lower reaches where sediments were commonly net autotrophic. Benthic microalgae (BMA) contributed up to $20 \%$ of the total carbon content in the lower estuary sands, while organic matter was dominated by phytodetritus and allochthonous material in the middle to upper estuaries. Sediment oxygen demand (SOD) incubations were carried out on surface sediments to investigate labile carbon contents. SOD normalised to sediment carbon content (SOD mol C ${ }^{-1}$ ) confirmed a much higher proportion of labile OM in the lower estuary sediments due to a predominance of living BMA, while the OM pool in the upper and middle estuaries was relatively more degraded. SOD mol $\mathrm{C}^{-1}$ correlated well with both the C:N and the chlorophyll:pheophytin ratios of surface sediments, providing 3 independent measures of sediment OM quality. Comparisons between SOD and benthic community respiration rates $\left(\mathrm{O}_{2}\right.$ fluxes) measured in sediment core incubations suggested that oxygen demand due to the oxidation of reduced sulphur compounds formed a significant fraction of the $\mathrm{O}_{2}$ flux, and that fluxes may be enhanced by bioturbation. $\mathrm{O}_{2}$ and $\mathrm{TCO}_{2}$ respiration rates were overall poorly correlated and suggested that benthic metabolism is characterised by periods of anaerobic mineralisation $\left(\mathrm{TCO}_{2}: \mathrm{O}_{2}>2\right)$ during periods of high OM supply, followed by aerobic respiration and reoxidation $\left(\mathrm{TCO}_{2}: \mathrm{O}_{2} \approx 1\right.$ to 2 ) as OM supply waned. At many sites throughout the study $\mathrm{TCO}_{2}: \mathrm{O}_{2}$ flux ratios were less than 1 and coupled with alkalinity uptakes, indicating that either sulphide oxidation or nitrification may be significant influences on the benthic fluxes. These processes cause a net drawdown on $\mathrm{O}_{2}$ effluxes that can lead to significant underestimations of benthic productivity. As such, the use of $\mathrm{CO}_{2}$ and $\mathrm{O}_{2}$ fluxes yield distinctly different measures of benthic metabolism.
\end{abstract}

KEY WORDS: Organic matter $\cdot$ Benthic metabolism $\cdot$ Respiratory quotient $\cdot$ Chlorophyll $\cdot$ Benthic microalgae Resale or republication not permitted without written consent of the publisher

\section{INTRODUCTION}

Estuarine foodwebs and nutrient cycling are controlled by the nature of organic matter (OM) supply and mineralisation in the pelagic and benthic compartments of the ecosystem (Alongi 1998). Accordingly, there has been considerable research effort directed at understanding $\mathrm{OM}$ cycling in estuarine and coastal environments, especially in areas affected by eutrophication (Richardson \& Jørgensen 1996). Due to high rates of OM deposition, sediments are often the focus of mineralisation studies and have traditionally been regarded as sites of heterotrophic metabolism. However, benthic community metabolism is also influenced by autotrophic production, which may occur to depths of greater than $15 \mathrm{~m}$ (Sundback 1986), and in shallow systems may result in net autotrophic benthic communities (Rysgaard et al. 1995, Sundback \& Miles 2000). BMA may also contribute labile carbon to the sedimentary $\mathrm{OM}$, thereby influencing heterotrophic meta- 
bolism (Christensen et al. 1990). In addition, the production of oxygen by BMA may alter the redox conditions of the sediments on a diurnal basis, thereby stimulating coupled nitrification-denitrification (Henriksen \& Kemp 1988, Risgaard-Petersen et al. 1994), sulphide oxidation (Weiland \& Kuhl 2000) and aerobic mineralisation (Aller 1994). As such, conceptual models of sediments as a zone of heterotrophic remineralisation (e.g. Billen \& Lancelot 1988, Boon et al. 1999) may not be applicable in many shallow estuaries.

In general, the quality, quantity and distribution of sedimentary $\mathrm{OM}$ are primary factors driving heterotrophic metabolism (Blackburn 1995). There are 2 primary fractions recognised as constituting this OM pool: the labile fraction of rapidly biodegradable organic compounds; and the refractory component of slowly biodegradable organic detritus (Newell et al. 1981, Billen \& Lancelot 1988). The labile fraction is of greatest interest to understanding benthic metabolism since the kinetics of mineralisation of this material are commonly up to an order of magnitude greater than the refractory pool (Lancelot \& Billen 1985) and are therefore a relatively more important influence on nutrient cycling (Klump \& Martens 1987). Measures of this labile pool mostly rely on proxies such as chl $a$, which is seen as representing freshly deposited phytoplankton material (Klump \& Martens 1987, van Duyl \& Kop 1994, Banta et al. 1995, Cherrier et al. 1996, Cowan \& Boynton 1996, Boon \& Duineveld 1998). However, few studies have distinguished between chl $a$ and its degradation products, making the measure somewhat crude since pheophytin may constitute the most abundant chloropigment in sediments and differ from chl $a$ in lability (Barranguet et al. 1997).

Another measure of OM quality at the sediment surface is the carbon:nitrogen ratio (C:N) of particulate material (Rice 1982, Cifuentes et al. 1996, Kepkay et al. 1997). The C:N ratio of living microalgae cells (which represent a significant source of labile material in estuaries) is reasonably constant at ca. 6.6 (Redfield ratio; Redfield 1934), although this may vary according to the ambient inorganic nitrogen concentration and growth rates (Lancelot \& Billen 1985). The C:N of algal detritus increases from near Redfield to approximately 10 as it is degraded by bacterial processes (Lancelot \& Billen 1985, Blackburn et al. 1996, Pedersen et al. 1999). In contrast, allochthonous $\mathrm{OM}$ has a much higher $\mathrm{C}: \mathrm{N}$ and tends to be more refractory than autochthonous algal detritus.

The rates and pathways of OM mineralisation are of primary interest in understanding ecosystem functioning and disturbances caused by eutrophication (D'Avanzo et al. 1996, Jørgensen 1996, Malone \& Conley 1996). The measurement of these metabolic pro- cesses in sediments is complicated by the spatial heterogeneity of benthic metabolism, both laterally and vertically through the sediment profile (Kerner 1993). Community respiration rates are commonly inferred from benthic fluxes of oxygen (Yoon \& Benner 1992, Cowan \& Boynton 1996, Middleburg et al. 1996, Rizzo \& Christian 1996, Hopkinson et al. 1999) and/or carbon dioxide (Hammond et al. 1985, Anderson et al. 1986, Kristensen \& Blackburn 1987, Berelson et al. 1998, Eyre \& Ferguson 2002). More detailed studies of OM mineralisation by sulphate reduction have been carried out using isotopic tracer incubations (Upton et al. 1993, Thamdrup \& Canfield 1996, Rysgaard et al. 1998, Alongi et al. 1999, Rysgaard et al. 2000). Flux studies have advantages in the integration of benthic community processes and the ability to simultaneously measure net nutrient fluxes; however, limitations arise due to the cryptic nature of oxygen and carbon dioxide fluxes. For example, oxygen may be consumed by aerobic OM mineralisation, chemoautotrophic nitrification, as well as by the chemical oxidation of reduced species such as sulphides. Furthermore, these interactions are likely to be affected by benthic microalgal production, and bioturbation. Carbon dioxide fluxes provide a more complete measure of OM degradation since they include anaerobic pathways; however, there are still complications due to the occurrence of nonbiogenic fluxes from calcium carbonate dissolution (Anderson et al. 1986, Berelson et al. 1998, Hammond et al. 1999), $\mathrm{CO}_{2}$ assimilation by chemoautotrophic bacteria, and to a lesser extent methane production.

This study aims to provide the basis for a conceptual understanding of OM cycling in shallow sub-tropical estuaries in Australia. OM supply and mineralisation in these estuaries is poorly described, and our limited understanding of these processes stems primarily from research carried out in similar sub-tropical systems in America (Twilley et al. 1999). Three estuaries were chosen to provide a range of different trophic states within the same broad category of estuary, thereby giving a more comprehensive picture of processes. It is hypothesised that BMA may impact significantly on OM supply and quality in the sediments, as well as directly and indirectly influencing benthic metabolism. The study characterises the sources and lability of OM along the estuarine gradients of these systems during 4 different seasons. Three different measures of labile carbon are investigated: sediment chloropigments, C:N ratio, and sediment oxygen demand (SOD). The relationships between $\mathrm{OM}$ and benthic metabolism are investigated, with particular attention paid to the role of BMA. Finally, the relationships between oxygen, carbon dioxide and alkalinity fluxes are investigated to infer the relative importance of oxic, suboxic, and anoxic metabolism in these estuaries. 


\section{MATERIALS AND METHODS}

Study area. Climate: The Brunswick and Sandon Rivers are located on the northern coast of New South Wales (NSW), Australia (Fig. 1). The climate is controlled by 2 major influences: the sub-tropical high pressure belt during winter-spring (July to October) bringing clear, mainly dry conditions; and easterly monsoonal tradewinds during summer-autumn (November to May) bringing warm, humid conditions. Tropical cyclones may affect the region between January and April, bringing heavy rainfalls (up to $400 \mathrm{~mm}$ $\mathrm{d}^{-1}$ ) and flooding. Major rainfall events may also occur due to the occurrence of intense low-pressure systems
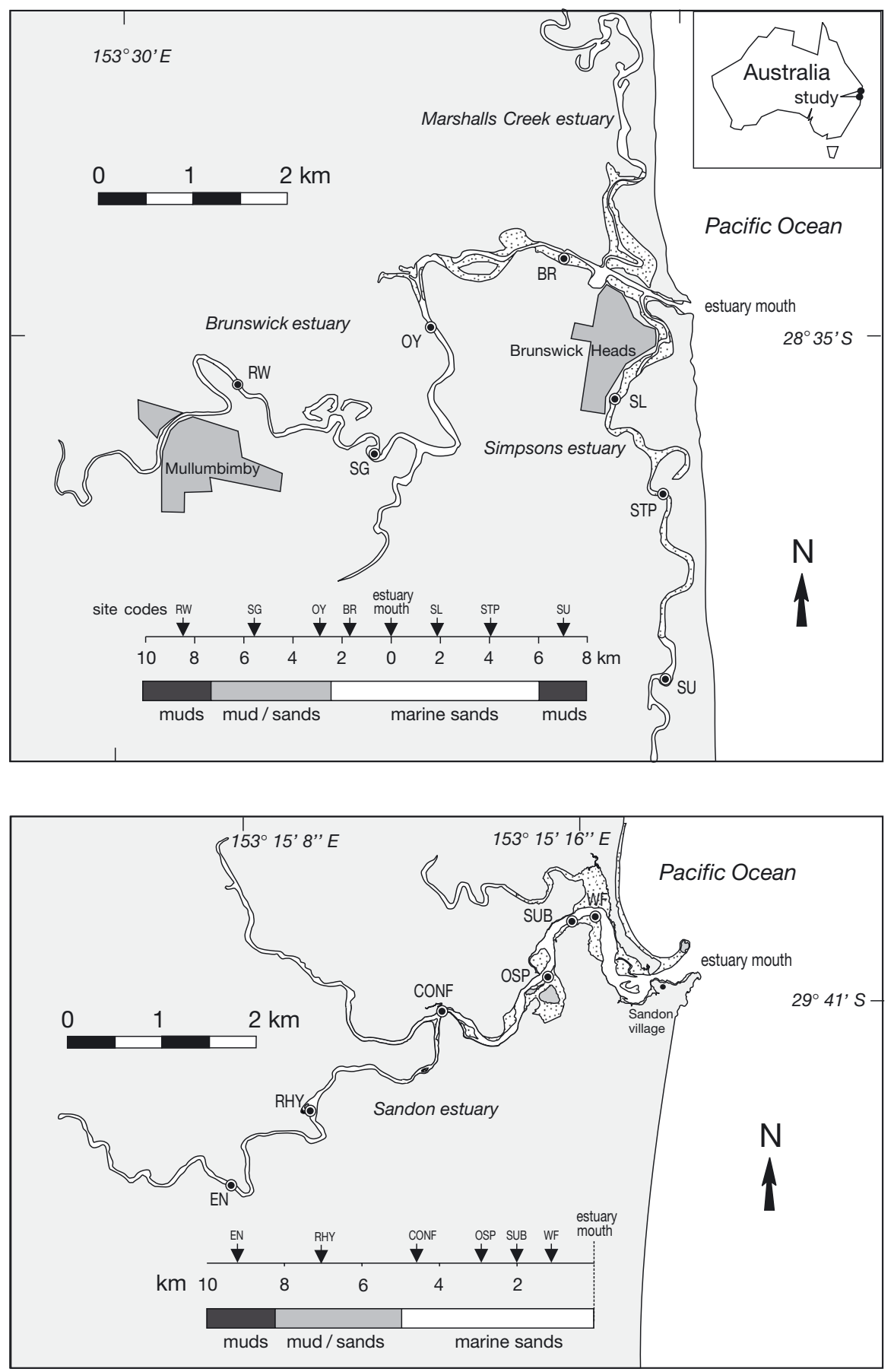

Fig. 1. The Brunswick-Simpsons estuary and Sandon estuary showing the locations of study sites 
off the NSW coast (East Coast Lows). The region experiences the highest annual rainfall in NSW, with a summer-autumn maximum (wet season), and lowest rainfall occurring during the winter-spring transition (dry season). There is high interannual variation in rainfall due to the influence of the Southern Oscillation on climate in the region: lower than average annual rainfalls occur during El Niño years (atmospheric pressure at Darwin > Tahiti), while greater than average rainfalls occur during La Niña years (atmospheric pressure at Darwin < Tahiti). Cyclone genesis tends to move east during El Niño years resulting in generally less cyclonic influence on the region's climate. Freshwater flows to the study estuaries are dominated by large, episodic, short-lived inputs during summer and very low flow in winter. The Brunswick estuary catchment receives approximately 1.5 times the average annual rainfall of the Sandon estuary catchment. The current study period spanned a range of climatic conditions, with 1997 and 1998 receiving mostly less than median rainfall, while 1999 received mostly greater than median rainfall. There were no floods during this period; however, there were several high flow events sampled during February and March 1999.

The Brunswick-Simpsons estuary system: The Brunswick-Simpsons estuary system has a total catchment area of approximately $218 \mathrm{~km}^{2}$. The Brunswick estuary forms the main arm of the system, while the Simpsons estuary forms the south arm and joins the main arm about $500 \mathrm{~m}$ from the ocean entrance. Marshalls Creek estuary forms the north arm of the system, joining the main arm about $500 \mathrm{~m}$ upstream of the Simpsons estuary. Up to $75 \%$ of the Brunswick-Simpsons estuary catchment has been cleared for agriculture and grazing, and $75 \%$ of the estuary shoreline has been modified. The main arm, Brunswick estuary, receives direct effluent discharges from 2 sewage treatment plants (STPs): 1 at Mullumbimby in the upper estuary (10.5 $\mathrm{km}$ from the estuary mouth), and 1 at Ocean Shores in the lower estuary $(3 \mathrm{~km}$ from the estuary mouth). The south arm, Simpsons estuary, receives sewage effluent from one STP located $3.5 \mathrm{~km}$ from the estuary mouth. Combined sewage discharges from all 3 plants dominated nitrogen and phosphorus loadings to the estuary system during the study period. The relative importance of STP loadings increases during low flow conditions (Ferguson et al. unpubl.). The main arm Brunswick estuary also receives storm water runoff from the townships of Mullumbimby $\left(2.5 \mathrm{~km}^{2}\right)$. Urban runoff from Brunswick Heads $\left(0.08 \mathrm{~km}^{2}\right)$ is distributed equally to the lower main arm and south arm estuaries.

The Sandon estuary: The Sandon River has a catchment of approximately $100 \mathrm{~km}^{2}$. Due to low freshwater inputs for much of the year, the head of the Sandon estuary rarely drops below a salinity of 15 , and during the dry season the head of the estuary may reach salinities of 30. Salinity is often depressed along the middle stretches of the estuary indicating groundwater inputs from extensive low-lying swamps adjacent to this part of the estuary. In contrast to the Brunswick River, there is no urban or agricultural development in the Sandon catchment. Main disturbances are small-scale logging operations and sparse cattle grazing in the upper catchment.

Site selection. A pilot survey of sediment carbon, nitrogen and phosphorus was undertaken to broadly characterise sediment quality of subtidal shoals along the estuarine gradient of the Brunswick-Simpsons estuary system and the Sandon estuary. Three basic sediment types were identified: (1) fine-grained, organic-rich muds in the upper estuary; (2) organicrich, aeolian/fluvial sands in the middle estuary; and (3) organic-poor, marine sands in the lower estuary. There was little cross-sectional variability in the upper and lower estuaries, while in the middle estuaries variability between left and right banks tended to be much higher.

Sites were chosen along the estuarine gradients of the Brunswick-Simpsons and Sandon estuaries in an attempt to broadly characterise zones of common sediment and water quality conditions (Fig. 1, Table 1) in the upper, middle and lower estuary during average flow. The study estuaries may be flushed fresh to the mouth during high flow events (Eyre 2000), thus all sites may be periodically subject to freshwater conditions and sediment scouring. Tides along the sub-tropical Australian east coast are semi-diurnal and tidal range is up to $2 \mathrm{~m}$ during spring tides, and $<1 \mathrm{~m}$ during neap tides. Sample sites were established on subtidal shoals within $10 \mathrm{~m}$ of the bank, and a mean depth of $0.75 \mathrm{~m}$ at low tide. These shoals are within the photic zone throughout the tidal cycle and therefore represent potentially the most productive subtidal sediments at each site. In the middle estuaries, where sediment quality was more variable, sites were chosen on shoals with the highest carbon content as these were likely to represent areas of maximal benthic metabolism. Sites were demarcated by $50 \mathrm{~mm}$ PVC poles so that the same location $( \pm 2 \mathrm{~m}$ ) was sampled during each season.

Benthic process measurements. Benthic metabolism and sediment/water nutrient fluxes were measured using on-site sediment core incubations which maintain the diel and diurnal rhythms of the benthic communities under close to in situ light and temperature conditions. Triplicate sediment cores (approximately $20 \mathrm{~cm}$ long) including overlying water (approximately $2.3 \mathrm{l}$ ) were collected from each site in $50 \mathrm{~cm}$ long, $95 \mathrm{~mm}$ ID clear acrylic pipes using a remote coring 
Table 1. Sediment type and physico-chemical conditions at sample sites in the Brunswick-Simpsons estuary system and the Sandon estuary

\begin{tabular}{|c|c|c|c|c|c|c|c|}
\hline Estuary & Site & $\begin{array}{c}\text { Estuarine } \\
\text { zone }\end{array}$ & $\begin{array}{l}\text { Sediment } \\
\text { type }\end{array}$ & $\begin{array}{c}\text { Average carbon } \\
\text { content } \\
(\%)\end{array}$ & $\begin{array}{l}\text { Average high } \\
\text { tide depth } \\
\text { (m) }\end{array}$ & $\begin{array}{c}\text { Annual } \\
\text { temperature } \\
\text { range }\left({ }^{\circ} \mathrm{C}\right)\end{array}$ & $\begin{array}{c}\text { Average } \\
\text { water column } \\
\text { salinity (PSU) }\end{array}$ \\
\hline \multirow{4}{*}{ Brunswick } & RW & Upper & Fine grained mud & 5.17 & 1 & $15-30$ & $8 \pm 4$ \\
\hline & $\mathrm{SG}$ & Mid & Mud/fluvial sand & 1.52 & 1.2 & $17-28$ & $20 \pm 5$ \\
\hline & OY & Mid & Mud/fluvial sand & 2.90 & 1.5 & $17-26$ & $32 \pm 2$ \\
\hline & $\mathrm{BR}$ & Lower & Marine sand & 0.66 & 2 & $17-26$ & $35 \pm 2$ \\
\hline \multirow[t]{3}{*}{ Simpsons } & $\mathrm{SU}$ & Upper & Mud/aeolian sand & 6.21 & 1.5 & $14-30$ & $23 \pm 5$ \\
\hline & STP & Mid & Marine/aeolian sand & 0.14 & 1.5 & $16-28$ & $28 \pm 3$ \\
\hline & $\mathrm{SL}$ & Lower & Marine sand & 0.15 & 1 & $18-26$ & $34 \pm 3$ \\
\hline \multirow[t]{6}{*}{ Sandon } & EN & Upper & Mud & 2.79 & 2 & $14-31$ & $15 \pm 6$ \\
\hline & RHY & Mid & Mud/fluvial sand & 2.41 & 1.5 & $15-28$ & $25 \pm 5$ \\
\hline & CONF & Mid & Fluvial/aeolian sand & 0.65 & 1.75 & $17-28$ & $30 \pm 5$ \\
\hline & OSP & Lower & Marine/aeolian sand & 0.27 & 1 & $17-26$ & $32 \pm 4$ \\
\hline & SUB & Lower & Marine sand & 0.10 & 1.5 & $17-26$ & $35 \pm 2$ \\
\hline & WF & Lower & Marine sand & 0.20 & 1 & $17-26$ & $35 \pm 2$ \\
\hline
\end{tabular}

device. Cores were examined to ensure that the bulk of the sediment surface was intact and discarded if disturbed. Cores were shaded and transported to the incubation site, where the overlying water was removed and gently replaced (ensuring no resuspension of the sediment surface) with water collected from the sample site at high tide and filtered through GF/C glass-fibre filters to remove zooplankton and large phytoplankton. They were then sealed air-tight with a clear acrylic lid (including sample ports and a Teflon stir bar suspended approximately $15 \mathrm{~cm}$ from the sediment surface), placed in a floating incubation cradle in the estuary (with the sediment surface at a depth of approximately $50 \mathrm{~cm}$ ) and allowed to equilibrate to temperature and light conditions for approximately $3 \mathrm{~h}$. Stirring rate was adjusted to just below the threshold for resuspension. Whilst this may not truly represent in situ conditions where sediment resuspension may occur readily due to tidal currents and wind waves, it was considered appropriate since the focus of the study was to investigate benthic microbial processes rather than attempt to quantify in situ fluxes.

Incubations were run over $36 \mathrm{~h}$, with the first samples taken at sunset on the day of core collection and subsequent samples taken at midnight, dawn, midday, sunset and dawn. This was done to ensure that benthic communities were kept as fresh as possible and in step with their diel light/dark cycles. At each sample time, dissolved oxygen concentrations $\left( \pm 0.01 \mathrm{mg} \mathrm{l}^{-1}\right)$ and $\mathrm{pH}$ $( \pm 0.002 \mathrm{pH}$ units $)$ were measured directly via a port in the lid using a YSI 5000 BOD probe and Denver pH probe respectively. Samples for alkalinity and dissolved nutrients were withdrawn via a separate port and filtered through a $0.45 \mu \mathrm{m}$ cellulose acetate filter into $10 \mathrm{ml}$ acid-rinsed and sample-rinsed polyethylene vials. As samples were taken, an equal amount of replacement water was automatically drawn into the incubation chamber from a reservoir of filtered site water. Samples for alkalinity and silicate were immediately refrigerated at $4^{\circ} \mathrm{C}$ and nutrient samples were frozen at $-20^{\circ} \mathrm{C}$. A blank of each water type was also sampled for dissolved oxygen and $\mathrm{pH}$.

Alkalinity and carbon dioxide. Alkalinity was determined in the laboratory within $15 \mathrm{~d}$ using Gran titrations (Stumm \& Morgan 1989). A total of $10 \mathrm{ml}$ of sample at $20^{\circ} \mathrm{C}$ was transferred to a titration vessel containing a teflon stir bar and standard additions of $0.01 \mathrm{M} \mathrm{HCl}$ acid were made using a Hamilton ${ }^{\mathrm{TM}}$ Microlab Auto Dilutor. Changes in $\mathrm{pH}( \pm 0.002 \mathrm{pH}$ units) were tracked using a Denver $\mathrm{pH}$ probe calibrated against standard NBS buffers at $20^{\circ} \mathrm{C}$ every 18 samples. Samples from each incubation time series were run in sequence to minimise error in flux calculations introduced by instrument drift. Total carbonate $\left(\mathrm{TCO}_{2}\right)$ was calculated using alkalinity, salinity, temperature and $\mathrm{pH}$ measured at time of sampling according to equations given by Almgren et al. (1983).

Use of blanks. This study used blanks of each water type to assess the potential for microbial activity in the overlying water column by monitoring changes in $\mathrm{O}_{2}$ concentrations. The filtration of replacement water using GF/C filters was found to remove between 95 and $98 \%$ of phytoplankton present in the water. While no assessment was made of the removal efficiency for bacteria, blank $\mathrm{O}_{2}$ measurements showed that $\mathrm{O}_{2}$ concentration changes were minimal in the filtered water, and it was therefore assumed that most of the microbial activity of the water was removed by filtration. 
Benthic flux calculations. Benthic fluxes of nutrients across the sediment-water interface were calculated using the following formula:

$$
\mathrm{BF}=\left(\left[C_{t 1}-C_{t 0}\right] \times V / \mathrm{SA}\right) / T
$$

where $\mathrm{BF}=$ benthic flux of nutrient $\left(\mu \mathrm{mol} \mathrm{m} \mathrm{m}^{-2} \mathrm{~h}^{-1}\right)$, $C_{t 0}=$ nutrient conc. $\left(\mu \mathrm{mol} \mathrm{l}^{-1}\right)$ in overlying water at the start of time period, $\mathrm{C}_{t 1}=$ nutrient conc. $\left(\mu \mathrm{mol} \mathrm{l^{-1 }}\right)$ in overlying water at the end of time period, $V=$ volume of overlying water (l) in the incubation chamber, $\mathrm{SA}=$ surface area of sediment $\left(\mathrm{m}^{2}\right)$ in the incubation chamber, $T=$ time $(\mathrm{h})$.

Dark flux rates were calculated using concentration data from the first dark period of the incubation (i.e. sunset to dawn), and net light fluxes were calculated using the second $12 \mathrm{~h}$ (dawn to sunset). Gross benthic primary productivity was calculated by subtracting dark $\mathrm{O}_{2} / \mathrm{TCO}_{2}$ flux rates (respiration) from net light rates (respiration + productivity). Net daily flux rates were calculated as the difference between concentrations at the start and the end of the diurnal period (sunset to sunset).

Diurnal productivity/respiration $(p / r)$ values were calculated as the gross diurnal productivity divided by gross diurnal respiration. While benthic productivity was measured at most sites during this study, it should be stressed that these measurements represent maximum productivity. All sites had an average water depth of approximately $0.75 \mathrm{~m}$ at neap low tide, therefore the incubation experiments (carried out at a depth of $0.6 \mathrm{~m}$ ) approximate low tide conditions, and the productivity measured represents an estimate of maximum in situ rates during the occurrence of low tide in the middle of the day (i.e. maximal light availability). Obviously, in situ light conditions will vary dramatically according to tide, turbidity and clouds, and measured rates will provide an overestimate of total productivity if integrated over time periods of weeks or seasons.

Sediment chlorophyll and solid phase analysis. Samples for sediment carbon, nitrogen and chlorophyll analysis were collected from all sediment cores following the completion of benthic flux experiments. Chlorophyll samples were collected from the top $2 \mathrm{~mm}$ of the sediment surface and extracted in 90\% HPLC grade acetone at $-20^{\circ} \mathrm{C}$ until analysis (within $2 \mathrm{wk}$ ). Storage tests of sediment chlorophyll extracts from each site showed no significant degradation of chloropigments over this storage period. Carbon and nitrogen samples were collected from the top $5 \mathrm{~mm}$ of the sediment surface and stored at $-20^{\circ} \mathrm{C}$ until analysis. Prior to analysis, sediment chlorophyll samples were sonicated for $15 \mathrm{~min}$, then centrifuged at $6250 \times g$ for 5 min before being analysed by spectrophotometry. Chls $a, b, c$, and pheophytin were calculated according to the equations given by Jeffrey \& Welschmeyer (1997). Sediment chlorophyll was expressed as $\mathrm{mg} \mathrm{m}^{-2}$. Total sediment carbon and nitrogen were determined by a LECO CNS analyser.

Sediment oxygen demand. A known volume $(3 \mathrm{ml})$ sample of the top $5 \mathrm{~mm}$ of sediment was taken from each core and placed into a $300 \mathrm{ml}$ glass BOD bottle containing $0.45 \mu \mathrm{m}$ filtered site water. The bottle was capped and shaken, then allowed to sit for $30 \mathrm{~min}$. This was done to satisfy any rapid chemical oxygen demand before the initial oxygen measurements were taken. Tests showed that the rate of $\mathrm{O}_{2}$ consumption dropped off rapidly, within about 30 min of mixing sediment and water, to a constant rate which held for $>120 \mathrm{~h}$. Dissolved oxygen was measured using a YSI 5000 BOD probe and the bottle was recapped and placed into a light-proof container and immersed in the estuary to maintain a constant temperature. Three blanks of the filtered water were also incubated to allow for oxygen changes in the water alone. Dissolved oxygen was reread at 24 and $48 \mathrm{~h}$. A replicate sample $(3 \mathrm{ml})$ of each sediment core was also taken and placed into pre-weighed polyethylene vials and stored at $-20^{\circ} \mathrm{C}$ until analysis for bulk density. The total SOD of each sediment sample was estimated as $\mathrm{mg} \mathrm{O}_{2}$ consumed per gram of dry sediment. The lability of organic carbon was estimated by normalising the sediment SOD to the carbon content of the sample, expressed as mmol $\mathrm{O}_{2}$ consumed per mol of organic carbon.

\section{RESULTS}

\section{Benthic chlorophyll pigments}

The total chlorophyll content of the top $2 \mathrm{~mm}$ of sediment was consistently highest in the lower estuary sand shoals of all 3 systems (up to $90 \mathrm{mg} \mathrm{m}^{-2}$ in the lower Sandon during summer) (Fig. 2). The exception to this trend was at site SUB in the Sandon, which is subject to high tidal currents and frequent disturbance due to the migration of sand shoals in the form of mega ripples. Chlorophyll concentrations generally decreased up the estuarine gradient in the Brunswick and Simpsons estuaries, whereas they were more constant along the Sandon estuary. The opposite trend was observed with pheophytin content, which generally increased towards the top of all 3 estuaries (up to $32 \mathrm{mg} \mathrm{m}^{-2}$ in the Sandon estuary), with the exception of winter in the Sandon, where pheophytin peaked at Site CONF (see Fig. 1 for site locations) in the middle estuary. Overall, total chlorophyll and pheophytin trends along each estuary did not differ significantly between seasons, apart from a large increase in chlorophyll in the lower Sandon during summer and 

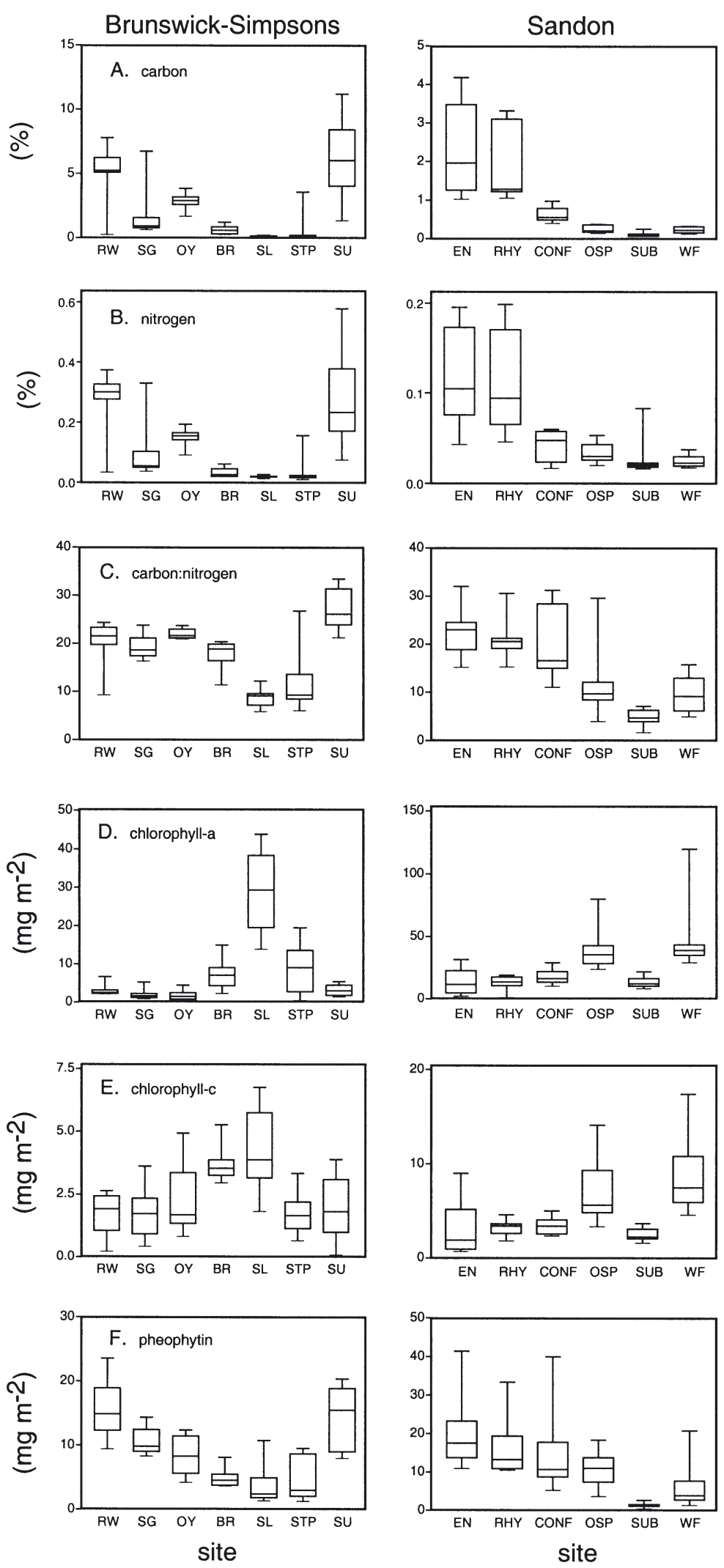

Fig. 2. Surface sediment properties at the sample sites along the Brunswick, Simpsons and Sandon estuaries. Data for each site comprises triplicate measurements taken during 4 seasons (see Fig. 1 for locations) the mid-estuarine peak in pheophytin during winter. Ratios of chls $a, b$ and $c$ varied markedly within and between estuaries indicating various benthic microalgal communities. Chl a was ubiquitous in all samples, as would be expected since it is a pigment common to all photosynthetic organisms; however its relative abundance varied from less than $40 \%$ in the upper estuarine sites to greater than $90 \%$ in the lower estuarine sites. Chl $b$ was a significant fraction (up to $30 \%$ ) of the total pigments in the Brunswick estuary during most of the year (except autumn when it was largely absent). Otherwise, chl $b$ formed only a minor fraction of total chlorophyll concentrations in the other systems. Chl $C$ was present at all sites during all seasons except in the upper Brunswick and Simpsons estuaries during the summer wet season.

\section{Sediment carbon and nitrogen}

There was a general increase in sediment carbon and nitrogen content towards the top of each estuary with a strong linear relationship $\left(\mathrm{r}^{2}=0.97\right)$ between the 2 parameters. The highest carbon contents were recorded at the upper Brunswick and Simpsons estuary sites (yearly average $5.17 \%$ C, $0.28 \% \mathrm{~N}$ and $6.2 \% \quad \mathrm{C}, \quad 0.28 \% \quad \mathrm{~N}$, respectively), which were almost twice the levels in the upper Sandon (yearly average $2.79 \%$ C, $0.14 \%$ N) (Fig. 2). The highest carbon content in the lower estuary sands occurred at Site BR in the Brunswick estuary $(0.66 \%$ C, $0.03 \% \mathrm{~N})$, with much lower levels in the lower Simpsons and Sandon estuaries $(0.14$ to $0.27 \%$ C, 0.02 to $0.04 \%$ $\mathrm{N})$. Seasonal variation in sediment carbon and nitrogen was generally low in all 3 systems, except in the upper Sandon and Simpsons estuaries, where there was steady increase throughout the study at Sites RHY and SUB, and a decrease at Site EN. C:N ratios in the Simpsons and Sandon estuaries increased along the estuarine gradient from values of $>10$ in the lower estuaries to $>20$ in the upper. In contrast, the C:N ratios along the Brunswick estuary were relatively constant at around 20. 


\section{Benthic metabolism}

Most sites displayed gross benthic productivity (oxygen production and carbon dioxide uptake during the light periods) throughout the year, with highest rates (up to $8000 \mu \mathrm{mol} \mathrm{O} \mathrm{m}^{-2} \mathrm{~h}^{-1}$ ) recorded in the lower estuarine sand shoals of all 3 systems (Table 2). The most productive areas were extensive subtidal shoals in the lower Sandon, which were not subject to significant shoal migration, thereby providing a more stable substrate for the growth of BMA. Productivity in the Sandon estuary was relatively stable throughout the year, although there was a significant increase along the entire estuary during the summer. In contrast, seasonal productivity was more variable in the Brunswick and Simpsons estuaries, with rates suppressed in the upper to middle estuaries during the autumn and summer wet season runs. This is most likely due to a combination of light limitation caused by high turbidity from freshwater runoff, and smothering of benthic communities by the settling out of suspended sediments (Gay 2002).

Oxygen uptake during the dark tended to be greatest at the organic/mud sites in the upper Brunswick and Simpsons estuaries and at Site OY in the midBrunswick estuary during autumn and summer (up to $-2200 \mu \mathrm{mol} \mathrm{O} \mathrm{O}_{2} \mathrm{~m}^{-2} \mathrm{~h}^{-1}$ ). Uptakes at the sand sites were also greatest during autumn and summer (up to $-2100 \mu \mathrm{mol} \mathrm{O} \mathrm{O}_{2} \mathrm{~m}^{-2} \mathrm{~h}^{-1}$ at Site SL in the lower Simpsons) but generally less than the upper and middle estuary sites with lowest values consistently recorded at site BR. Seasonal and spatial variations were less distinct in the Sandon estuary, and uptakes were on the whole smaller than in the Brunswick and Simpsons estuaries. There were relatively large uptakes (up to $-1950 \mu \mathrm{mol}$ $\mathrm{O}_{2} \mathrm{~m}^{-2} \mathrm{~h}^{-1}$ ) at Sites OSP and WF in the lower Sandon, coinciding with high productivity. Lowest uptake rates in the Sandon were nearly always recorded at Site SUB, where disturbance due to shoal migration was high and biological activity was suppressed.

The highest carbon dioxide effluxes during the dark were recorded at the upper and middle Brunswick estuary during summer $\left(4900 \mu \mathrm{mol} \mathrm{CO} \mathrm{CO}^{-2} \mathrm{~h}^{-1}\right)$, with the lower estuary sites in both the Brunswick and Simpsons recording dark uptakes. This trend was reversed during the winter with the highest $\mathrm{CO}_{2}$ effluxes occurring at the middle and lower estuary sites. Site SL in the lower Simpsons continued to have relatively high effluxes during spring along with Site RW in the upper Brunswick. Fluxes were generally of similar magnitude in the Sandon estuary with the highest fluxes recorded at Site OSP during the summer wet season (up to $3800 \mu \mathrm{mol} \mathrm{CO}_{2} \mathrm{~m}^{-2} \mathrm{~h}^{-1}$ ) and small dark uptakes recorded at sites EN, OSP and WF during winter. Light/dark variation of alkalinity fluxes in all 3 estuaries was largely characterised by efflux at night and either reduced efflux or uptake during the day (Table 2). The largest daytime uptakes in the Brunswick and Simpsons estuaries were recorded during winter and during summer in the Sandon. Net alkalinity fluxes in the Brunswick estuary throughout the study period showed a steady progression from uptake in the winter through to efflux during the summer, while the opposite trend was observed in the Sandon estuary.

Carbon dioxide effluxes during the dark in all 3 estuaries throughout the study were highly uncoupled to oxygen respiration with $\mathrm{TCO}_{2}: \mathrm{O}_{2}$ respiratory quotients ranging from approximately 0 to greater than 10 (Table 3). Large quotients for the net $24 \mathrm{~h}$ period reflect sites where the net change in $\mathrm{O}_{2}$ was close to zero.

Table 2. Dark and light fluxes of dissolved oxygen, total carbonate and alkalinity (mean \pm SD) at the study sites over the study period. The fluxes presented here integrate a degree of spatial (at approximately $1 \mathrm{~m}^{2}$ ) and temporal (seasonal) variability. Details of variability between sample times are given in 'Results: Benthic metabolism'. All units are $\mu m_{0} \mathrm{~m}^{-2} \mathrm{~h}^{-1}$, except alkalinity in $\mu$ eq $\mathrm{m}^{-2} \mathrm{~h}^{-1} ; \mathrm{n}=12$ for each site

\begin{tabular}{|c|c|c|c|c|c|c|c|}
\hline Estuary & Site & $\mathrm{O}_{2}$ dark & $\mathrm{O}_{2}$ light & $\mathrm{TCO}_{2}$ dark & $\mathrm{TCO}_{2}$ light & Alkalinity dark & Alkalinity light \\
\hline Brunswick & $\begin{array}{l}\text { RW } \\
\text { SG } \\
\text { OY } \\
\text { BR }\end{array}$ & $\begin{array}{r}-1545 \pm 684 \\
-1195 \pm 214 \\
-1464 \pm 648 \\
-519 \pm 351\end{array}$ & $\begin{aligned}-296 & \pm 824 \\
315 & \pm 1330 \\
-249 & \pm 838 \\
1978 & \pm 1312\end{aligned}$ & $\begin{aligned} 2254 & \pm 1420 \\
970 & \pm 529 \\
1559 & \pm 1235 \\
-37 & \pm 1281\end{aligned}$ & $\begin{array}{r}1776 \pm 2002 \\
-1065 \pm 2207 \\
-1115 \pm 3098 \\
-3217 \pm 754\end{array}$ & $\begin{aligned} 1730 & \pm 1861 \\
359 & \pm 917 \\
532 & \pm 1666 \\
194 & \pm 671\end{aligned}$ & $\begin{array}{r}1347 \pm 1959 \\
-612 \pm 1956 \\
-835 \pm 2568 \\
-1165 \pm 1084\end{array}$ \\
\hline Simpsons & $\begin{array}{l}\text { SU } \\
\text { STP } \\
\text { SL }\end{array}$ & $\begin{array}{l}-1505 \pm 453 \\
-1226 \pm 306 \\
-1406 \pm 508\end{array}$ & $\begin{aligned}-179 & \pm 976 \\
702 & \pm 789 \\
1623 & \pm 1229\end{aligned}$ & $\begin{aligned} 1043 & \pm 444 \\
561 & \pm 606 \\
937 & \pm 1472\end{aligned}$ & $\begin{aligned} 153 & \pm 1213 \\
-640 & \pm 457 \\
-2666 & \pm 1308\end{aligned}$ & $\begin{array}{r}687 \pm 463 \\
-213 \pm 528 \\
-872 \pm 509\end{array}$ & $\begin{aligned} 290 & \pm 969 \\
-441 & \pm 330 \\
-1944 & \pm 1266\end{aligned}$ \\
\hline Sandon & $\begin{array}{l}\text { EN } \\
\text { RHY } \\
\text { CONF } \\
\text { OSP } \\
\text { SUB } \\
\text { WF }\end{array}$ & $\begin{aligned}-1323 & \pm 426 \\
-1001 & \pm 394 \\
-715 & \pm 284 \\
-1217 & \pm 362 \\
-618 & \pm 319 \\
-1244 & \pm 406\end{aligned}$ & $\begin{aligned} 232 & \pm 975 \\
1163 & \pm 1038 \\
1645 & \pm 715 \\
2802 & \pm 2154 \\
1291 & \pm 769 \\
3330 & \pm 2177\end{aligned}$ & $\begin{aligned} 268 & \pm 982 \\
1188 & \pm 394 \\
690 & \pm 797 \\
1400 & \pm 1322 \\
759 & \pm 569 \\
532 & \pm 904\end{aligned}$ & $\begin{aligned} 128 & \pm 1274 \\
-1358 & \pm 1599 \\
-1886 & \pm 1116 \\
-3812 & \pm 3021 \\
-1616 & \pm 998 \\
-3840 & \pm 2556\end{aligned}$ & $\begin{aligned} 101 & \pm 942 \\
247 & \pm 467 \\
-123 & \pm 541 \\
512 & \pm 1330 \\
-21 & \pm 339 \\
-15 & \pm 997\end{aligned}$ & $\begin{aligned} 221 & \pm 1239 \\
-553 & \pm 967 \\
-262 & \pm 776 \\
-1162 & \pm 1738 \\
-295 & \pm 517 \\
-1038 & \pm 9083\end{aligned}$ \\
\hline
\end{tabular}


Table 3. Average $\mathrm{TCO}_{2}: \mathrm{O}_{2}$ ratio quotients for the dark, light and $24 \mathrm{~h}$ period at each of the study sites over the study period. Negative quotients indicate that the sediments were net heterotrophic with regard to $\mathrm{TCO}_{2}$ fluxes (i.e. net efflux), while positive quotients indicate net autotrophic sediments with regard to $\mathrm{TCO}_{2}$ fluxes (i.e. net uptake)

\begin{tabular}{|llrrrrrrr|}
\hline \multirow{2}{*}{ Estuary } & \multirow{3}{*}{ Site } & \multicolumn{2}{c}{ Dark } & \multicolumn{2}{c}{ Light } & \multicolumn{2}{c}{ Net 24 h } \\
& & Mean & SD & Mean & SD & Mean & SD \\
\hline Brunswick & RW & -1.23 & \pm 0.8 & -1.10 & \pm 2.9 & -4.38 & \pm 1.9 \\
& SG & -0.94 & \pm 0.3 & 0.78 & \pm 1.5 & 2.30 & \pm 5.2 \\
& OY & -1.29 & \pm 1.0 & 0.55 & \pm 2.8 & -1.34 & \pm 0.6 \\
& BR & -0.14 & \pm 1.8 & 1.22 & \pm 0.4 & 3.54 & \pm 2.1 \\
Simpsons & SU & -0.84 & \pm 0.4 & 0.00 & \pm 1.2 & -0.85 & \pm 3.0 \\
& STP & -0.49 & \pm 0.5 & 1.58 & \pm 3.9 & 0.28 & \pm 1.5 \\
& SL & -1.02 & \pm 1.7 & 4.26 & \pm 3.9 & 4.46 & \pm 4.9 \\
& EN & -0.35 & \pm 0.9 & 0.68 & \pm 2.5 & 0.22 & \pm 3.2 \\
& RHY & -1.41 & \pm 0.5 & 0.58 & \pm 2.7 & 0.12 & \pm 8.3 \\
& CONF & -0.60 & \pm 1.5 & 1.24 & \pm 0.4 & 2.37 & \pm 1.2 \\
& OSP & -1.23 & \pm 1.1 & 1.82 & \pm 1.1 & 6.62 & \pm 14.1 \\
& SUB & -1.46 & \pm 1.6 & 1.27 & \pm 0.2 & 1.70 & \pm 8.1 \\
& WF & -0.30 & \pm 0.6 & 1.74 & \pm 0.7 & 6.04 & \pm 4.3 \\
& & & & & & & \\
\hline
\end{tabular}

0.0001). The same relationships were also apparent between benthic productivity and sediment carbon. These relationships suggest that the influence of BMA on sediment carbon peaks in the highly productive lower estuary sediments, and wanes considerably in the middle and upper estuaries, where the background of detrital carbon increases markedly. This background is likely to be a result of allocthonous carbon inputs such as leaf litter fall in these parts of the estuary, or alternatively the build-up of refractory particulate material associated with degraded algae (see discussion below). Chloropigments become dominated by pheophytin (a degradation product of chl a) in the middle and upper estuaries, indicating degraded algal detritus and a predominance of heterotrophic activity (Bianchi et al.

\section{Net diurnal metabolism}

Net diurnal fluxes of both oxygen and carbon dioxide provide an indication of the net daily benthic community metabolism of sediments. Sediments in the upper Brunswick and Simpsons estuaries were consistently net heterotrophic for the entire study period in regards to $\mathrm{O}_{2}$, with only the lower estuary sand sites displaying net autotrophy. In contrast, most of the Sandon estuary sites (other than EN in the upper estuary) were net autotrophic during autumn, spring and summer, with a general shift towards heterotrophy during winter. Similar patterns emerged for net $\mathrm{CO}_{2}$ metabolism; however, a number of sites display net $\mathrm{TCO}_{2}$ uptake concomitant with net $\mathrm{O}_{2}$ uptake (Site SG during spring and Sites STP and SL during summer), and still more sites display disproportionately high $\mathrm{TCO}_{2}$ uptake compared to $\mathrm{O}_{2}$ production. The highly heterotrophic sites display the opposite tendency, with high $\mathrm{TCO}_{2}$ efflux relative to $\mathrm{O}_{2}$ uptake.

\section{DISCUSSION}

\section{Sources of sediment organic matter}

Sediment chl $c$ concentrations were positively correlated with gross benthic primary productivity $\left(\mathrm{r}^{2}=0.55\right.$, $\mathrm{p}<0.0001$ ), thereby providing a good proxy for benthic microalgae (BMA) biomass (Fig. 3). Chl $c$ was also positively correlated with sediment carbon in the lower estuaries $\left(r^{2}=0.42\right.$; $\left.p<0.0001\right)$ but negatively correlated in the middle and upper estuaries $\left(\mathrm{r}^{2}=0.45 ; \mathrm{p}=\right.$
1991). This would suggest a predominantly planktonic origin for this material rather than in situ production by BMA. A positive correlation between pheophytin and sediment carbon $\left(\mathrm{r}^{2}=0.37 ; \mathrm{p}<0.0001\right)$ indicates that phytodetritus may have a significant influence on sediment $\mathrm{OM}$ and hence metabolism due to its relatively labile nature (Christensen et al. 1990, Banta et al. 1995). Deposition of pelagic phytoplankton blooms has been identified as an important input of OM to estuarine sediments (Overnell et al. 1995, Malone \& Conley

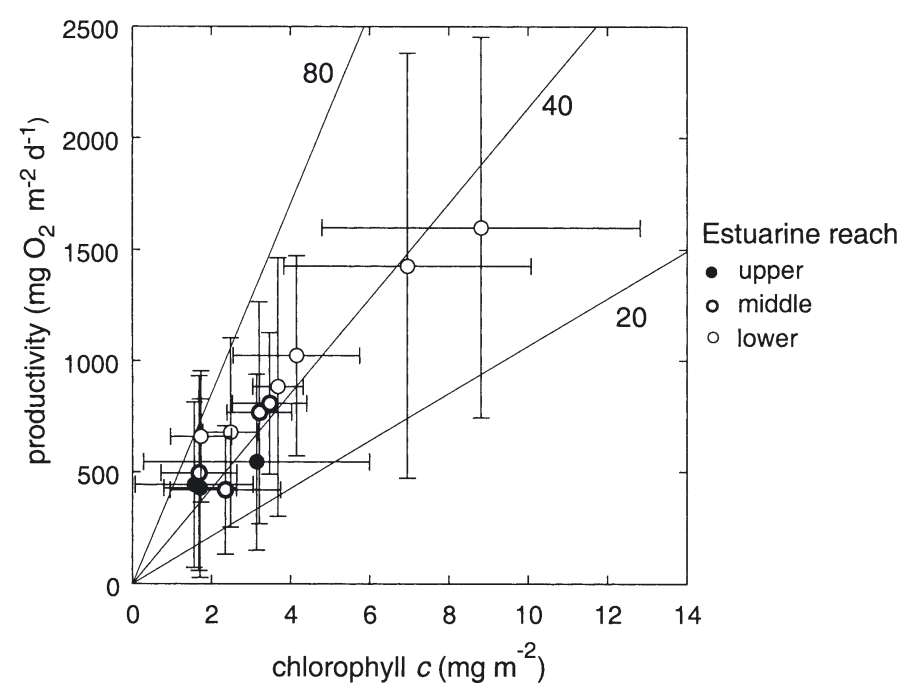

Fig. 3. Relationships between sediment $\mathrm{chl} c$ and gross primary productivity during the study (the 80,40 , and 20 lines refer to the chl a:carbon ratio using a chl $a$ : $c$ ratio of 5-see 'Sources of sediment organic matter'). Error bars are SD ( $\mathrm{n}=12)$ 
1996, Rysgaard et al. 1998), and this process is likely to be relatively more important in the middle to upper reaches of the Brunswick and Simpsons estuaries, where phytoplankton blooms are more common due to nutrient enrichment and longer freshwater residence times (Gay 2002, Ferguson et al. in press). In the Sandon estuary, the peak biomass of algal blooms is much smaller than the other systems, and therefore its upper and middle estuary sediments tend to be more influenced by living BMA.

The relative contributions of living BMA biomass to the sediment carbon pool may be estimated by applying a chlorophyll-to-carbon (biomass) conversion factor. The reported range for the ratio of biomass to chl a in pelagic phytoplankton varies between 22 and 154 (Valiela 1995) and may be as high as 200 (Parsons et al. 1977), while that of BMA averages about 42 within a range of 18 to 79 (Cadee \& Hegeman 1977, Gould \& Gallagher 1990, Valiela 1995, Kristensen et al. 1997). During the current study, chl $c$ yielded the tightest relationship with productivity, with maximum productivity and un-degraded biomass (chlorophyll:pheophytin $=1.7$ ) occurring at a chl $a: c$ of 5 , which suggests that diatoms are the predominant BMA taxa (Mackey et al. 1996). The chlorophyll specific productivity $\left(\mathrm{O}_{2}\right.$ $\mathrm{chl} \mathrm{a}^{-1} \mathrm{~d}^{-1}$ ) of BMA was estimated by assuming that the un-degraded biomass was in steady-state with $\mathrm{O}_{2}$ productivity over the diurnal cycle. Fig. 3 shows that chlorophyll-specific productivity averaged 40 and ranged between 20 and 80 between triplicates at some sites. The relative contributions of algal material to sediment OM during the current study were estimated assuming a carbon-to-chlorophyll ratio of 40 . Contributions averaged $0.7 \%( \pm 1.3 \%)$ in the upper estuaries, $1.9 \%( \pm 2.5 \%)$ in the middle estuaries, to around $8.6 \%$ $( \pm 5.6 \%)$ in the highly productive lower estuary sands, which is in agreement with estimations from other shallow estuarine systems (Cadee \& Hegeman 1977, Kristensen et al. 1997). Using total sediment chloropigments raises the percent contributions in the upper estuaries (where pheophytin concentrations are generally highest) by up to an order of magnitude.

The apparently low percentage $(<1 \%)$ of algal material in the upper estuary sediments suggests that other sources of organic carbon, such as leaf litter fall, may be the most important contributions to the high sediment carbon contents in these sediments. However $\mathrm{C}: \mathrm{N}$ ratios were not as high as values expected of terrestrial vascular plant material. The expected C:N range for fresh to degraded mangrove leaves is from approximately $>75$ through to $<40$ depending on the state of degradation (Lancelot \& Billen 1985, Cifuentes et al. 1996). Nitrogen enrichment of vascular plant detritus during degradation is thought to involve the formation of refractory humic compounds from more labile nitrogen forms such as polypeptides, phenols and amino-sugars (Rice 1982). If sediment OM were primarily comprised of terrestrial leaf litter as suggested by the relatively low proportions of algal material, C:N ratios should therefore be in excess of 30 . While this occurred in a minority of upper estuary sediments, C:N ratios generally fell within the range of 17 to 25. This suggests that microalgal detritus contributes more to sediment carbon than indicated by the sediment chloropigments alone. This may be partially due to the use of inappropriately low chlorophyll:carbon conversion factors, especially in the Brunswick estuary, where phytoplankton blooms are common throughout the year. However, even the use of the maximum reported conversion factor (200) still only yields an algal contribution of approximately $5 \%$ in the upper estuary. An alternative explanation may be the build-up of more refractory particulate fractions derived from the breakdown of algae (Henrichs \& Doyle 1986) that are no longer associated with chloropigments (Sun et al. 1991). Degraded algal detritus should have a $\mathrm{C}: \mathrm{N}$ ratio of approximately 10 (Rosenfield 1981); however, C:N ratios of up to 17 have been reported for sedimentary OM derived from phytoplankton in deep-sea sediments (Blackburn \& Henriksen 1983). The slightly higher maximal C:N ratios (25 to 30) observed in the upper and middle estuary sediments during this study implies that OM was influenced by a mixture of both algal and terrestrial detritus. Assuming a $\mathrm{C}: \mathrm{N}$ ratio of 10 for algal detritus and 40 for terrestrial material, there would be similar proportions of each material to give an overall $\mathrm{C}: \mathrm{N}$ ratio of 25. In the lower estuary sediments $\mathrm{C}: \mathrm{N}$ ratios tended to peak at around 10, suggesting that OM was dominated by algal detritus.

\section{SOD}

SOD measurements carried out in this study measured the combined chemical and biological oxygen demand (COD and BOD) of the top $1 \mathrm{~cm}$ of sediment. Due to the small sample size (approximately $2 \mathrm{~cm}^{3}$ ) and collection techniques, all macrofauna were excluded from measurements, meaning that the biological component of the oxygen demand was most likely due to microbes and meiofauna. Sulphur-oxidising bacteria comprise many genera, and their carbon metabolism may range from complete autotrophy to heterotrophy (Gijs Kuenen 1989). Autotrophic carbon fixation by sulphur-oxidising bacteria can represent a significant organic carbon source to the sediments (Joint \& Morris 1982), thus in the presence of significant concentrations of reduced sulphur, the SOD incubations may reflect carbon fixation as well as mineralisation. Fur- 
thermore, the oxidation of ammonia by chemoautotrophic nitrifying bacteria may add to carbon fixation. It is likely therefore that SOD includes a small COD, and a much larger BOD that is comprised of various components of heterotrophic oxygen demand (HOD) and autotrophic oxygen demand (AOD).

SOD rates displayed a weak positive relationship (combined estuaries $\mathrm{r}^{2}=0.11$ ) with dark oxygen flux (benthic community respiration) rates measured in intact sediment cores from the same sites. In general, respiration rates ranged between 1 and 4 times the SOD rates from corresponding sites. The greatest discrepancy occurred at sites where bioturbation was high, especially the lower estuary sand sites, where high densities of meiofauna within the upper $5 \mathrm{~cm}$ of sediment created a 'honeycomb' texture. Bioturbation and irrigation by meiofauna has been shown to increase the transport of solutes in sediments (Berg et al. 1998, Banta et al. 1999) and stimulate $\mathrm{O}_{2}$ consumption by up to 3 to 4 times (Devol \& Christensen 1993, Rysgaard et al. 2000). The respiration rate measurements are therefore likely to include the HOD due to the mineralisation of $\mathrm{OM}$ at the sediment surface, as well as the AOD/COD (due to sulphide oxidation and nitrification) from deeper sediments. This is supported by the co-occurrence of a peak in alkalinity fluxes (which may partly be attributed to high rates of sulphur cycling, and/or nitrification) at sites with high respiration:SOD ratios (see discussion in subsection 'Benthic respiration').

\section{Measures of labile carbon}

The SOD measurements include both AOD, which is directly related to living cells, and HOD, which is related to both living cells and labile organic substrates. Due to the potentially rapid turnover of live bacteria and their dissolved organic exudates (Meyer-Reil 1986, 1987), the combined AOD and HOD (i.e. SOD) may therefore be regarded as a rough measure of the relative importance of the labile carbon pool. Dissolved organic carbon exudates from BMA may also contribute to the labile carbon pool and have also been shown to be directly related to the SOD (Koster \& Meyer-Reil 2001). There was a positive relationship between the total sediment carbon content and SOD $\left(\mathrm{r}^{2}=0.43, \mathrm{p}<\right.$ 0.0001), indicating that the labile carbon pool increases concomitant with total carbon content along the estuarine gradients. In the lower estuaries there was also a positive relationship between chl $c$ and SOD $\left(\mathrm{r}^{2}=0.3\right.$, $\mathrm{p}=0.009$ ), supporting the hypothesis that BMA may contribute to labile carbon in highly productive sediments and indicating that $\mathrm{chl} c$ may provide a rough proxy for labile carbon in euphotic sediments.
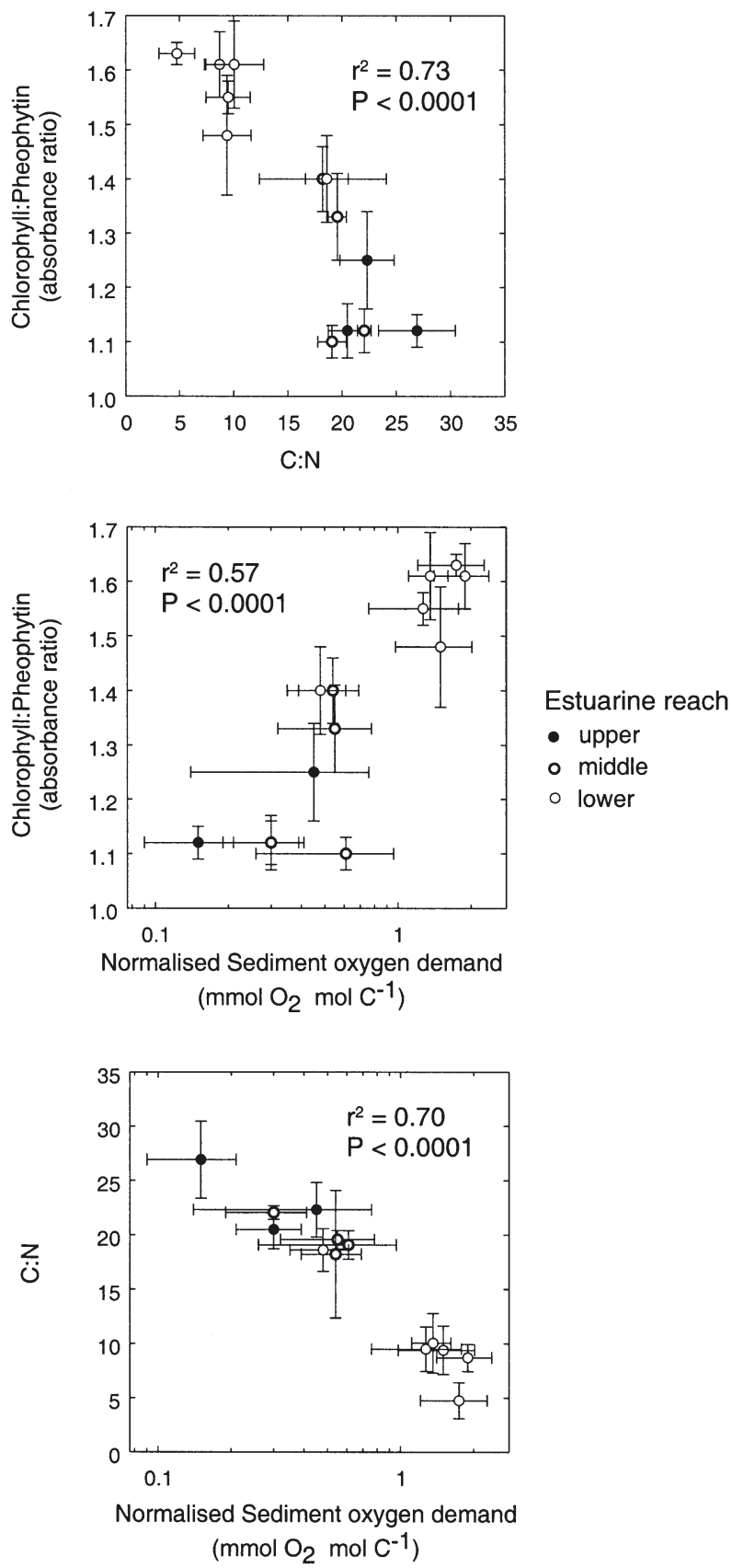

Fig. 4. Correlations between different measures of labile organic matter quality. Error bars are SD $(n=12)$

Normalisation of SOD to sediment carbon content (SOD mol $\mathrm{C}^{-1}$ ) provides a measure of oxygen consumed relative to carbon content, allowing an assessment of the proportion of labile material in the sediment carbon pool (i.e. a high SOD mol $\mathrm{C}^{-1}$ indicates relatively more labile material and visa versa). Fig. 4 shows the relationships between SOD mol $\mathrm{C}^{-1}$ and $\mathrm{C}: \mathrm{N}$ and chlorophyll:pheophytin absorbance ratios (chl:pheo). Low values for SOD mol $\mathrm{C}^{-1}$ at the upper 
Table 4. Major diagenetic reactions likely to occur in estuarine sediments

\begin{tabular}{|c|c|c|c|}
\hline Diagenetic reaction & Reaction & $\begin{array}{l}\text { linity change for } \\
\text { ward reaction }\end{array}$ & Eq. \\
\hline Respiration $(\Rightarrow) /$ photosynthesis $(\Leftarrow)$ & $\begin{array}{l}\text { Redfield algae } \\
\left\{\mathrm{C}_{106} \mathrm{H}_{263} \mathrm{O}_{110} \mathrm{~N}_{16} \mathrm{P}\right\}+107 \mathrm{O}_{2}+14 \mathrm{H}^{+} \Leftrightarrow \\
106 \mathrm{CO}_{2}+16 \mathrm{NH}_{4}{ }^{+}+\mathrm{HPO}_{4}{ }^{2-}+108 \mathrm{H}_{2} \mathrm{O}\end{array}$ & Increase & $(1)$ \\
\hline Nitrification & $\mathrm{NH}_{4}^{+}+2 \mathrm{O}_{2} \Rightarrow \mathrm{NO}_{3}^{-}+\mathrm{H}_{2} \mathrm{O}+2 \mathrm{H}^{+}$ & Decrease & $(2)$ \\
\hline Denitrification & $5\left\{\mathrm{CH}_{2} \mathrm{O}\right\}+4 \mathrm{NO}_{3}^{-}+4 \mathrm{H}^{+} \Rightarrow 5 \mathrm{CO}_{2}+2 \mathrm{~N}_{2}+7 \mathrm{H}_{2} \mathrm{O}$ & Increase & $(3)$ \\
\hline Pyrite oxidation & $\mathrm{FeS}_{2}(\mathrm{~s})+{ }^{15} /{ }_{4} \mathrm{O}_{2}+31 /{ }_{2} \mathrm{H}_{2} \mathrm{O} \Rightarrow \mathrm{Fe}(\mathrm{OH})_{3}(\mathrm{~s})+4 \mathrm{H}^{+}+2 \mathrm{SO}_{4}{ }^{2-}$ & Decrease & $(4)$ \\
\hline Sulphide oxidation & $\mathrm{H}_{2} \mathrm{~S}-+2 \mathrm{O}_{2} \Rightarrow \mathrm{SO}_{4}^{2-}+2 \mathrm{H}^{+}$ & Decrease & $(5)$ \\
\hline Sulphate reduction & $\mathrm{SO}_{4}{ }^{2-}+2 \mathrm{CH}_{2} \mathrm{O}+2 \mathrm{H}^{+} \Rightarrow 2 \mathrm{CO}_{2}+\mathrm{H}_{2} \mathrm{~S}^{-}+\mathrm{H}_{2} \mathrm{O}$ & Increase & (6) \\
\hline $\begin{array}{l}\text { Calcium carbonate dissolution }(\Rightarrow) / \\
\text { precipitation }(\Leftarrow)\end{array}$ & $\mathrm{CaCO}_{3}+\mathrm{CO}_{2}+\mathrm{H}_{2} \mathrm{O} \Leftrightarrow \mathrm{Ca}^{2+}+2 \mathrm{HCO}_{3}^{-}$ & Increase & (7) \\
\hline
\end{tabular}

and middle estuary sites coincide with high $\mathrm{C}: \mathrm{N}$ ratios of $>20$ as well as chl:pheo ratios of 1, confirming that the bulk of the OM at these sites is degraded and more refractory. In the lower estuary sites, SOD mol $\mathrm{C}^{-1}$ values increase as the chl:pheo ratios approach 1.7 (undegraded algal biomass) and $\mathrm{C}: \mathrm{N}$ ratios approach 6.625 (Redfield composition). Thus, although sediment carbon content is an order of magnitude lower in the lower estuary sediments, it is much more highly labile and associated with BMA biomass. Labile material in these sediments may also be due to the release of dissolved organics from living cells, which are thought to yield higher energy for heterotrophs than particulate detritus (Newell et al. 1981). The increase in the lability of the OM pool would stimulate higher heterotrophic microbial and meiofaunal activity per unit carbon (Lancelot \& Billen 1985, Kristensen et al. 1997).

\section{Benthic respiration}

The relationships between dark $\mathrm{O}_{2}$ uptakes and $\mathrm{TCO}_{2}$ effluxes in benthic systems result from a complex 3D mosaic of biogenic and chemical reactions (Table 4). Total carbonate fluxes $\left(\mathrm{TCO}_{2}\right)$ are produced by aerobic and anaerobic respiration (Eqs. 1, $3 \& 6$; refer to Table 4 for all equations) as well as by calcium carbonate $\left(\mathrm{CaCO}_{3}\right)$ dissolution/precipitation (Eq. 7) and are therefore not likely to correlate well with $\mathrm{O}_{2}$ in a dynamic system. As calcium fluxes were not measured during the present study it was not possible to accurately constrain the likely contribution of $\mathrm{CaCO}_{3}$ dissolution/precipitation to $\mathrm{TCO}_{2}$ fluxes. However, simple stoichiometric models accounting for the maximum contributions of likely diagenetic processes can shed light on benthic metabolism.

There were no clear relationships between $\mathrm{TCO}_{2}$ and $\mathrm{O}_{2}$ fluxes during the dark, suggesting a range of different metabolic conditions exists both temporally and spatially in these estuaries (Fig. 5). Variable $\mathrm{TCO}_{2}: \mathrm{O}_{2}$ flux ratios have been reported in the literature (e.g. Hopkinson et al. 1999); however, interpretations of these trends have excluded references to $\mathrm{CaCO}_{3}$ dissolution/precipitation and directly measured alkalinity fluxes, both of which are integral to understanding metabolic fluxes (Hammond et al. 1999). In many cases during the current study, the $\mathrm{TCO}_{2}: \mathrm{O}_{2}$ flux ratio fell within the range expected for aerobic respiration alone (1:1), and coupled with $\mathrm{CaCO}_{3}$ dissolution (2:1) (Eqs. $1 \& 7$ ). Very few points actually attain a ratio of 2:1 suggesting an incomplete response in the carbonate buffer system to biogenically produced $\mathrm{CO}_{2}$ from respiration, or alternatively the co-occurrence of other processes such as sulphide oxidation or nitrification (see discussion below). This is confirmed by alkalinity: $\mathrm{O}_{2}$ flux ratios, which generally fall short of the expected relationship (1.13:1) for aerobic respiration coupled with $\mathrm{CaCO}_{3}$ dissolution. There was evidence of anaerobic respiration with $\mathrm{TCO}_{2}: \mathrm{O}_{2}$ flux ratios exceeding 2:1 during summer at 2 sites in the middle and upper Brunswick estuary and at sites in the lower estuaries of all 3 systems. The alkalinity: $\mathrm{O}_{2}$ flux ratios at the upper Brunswick site approached 3:1 suggesting that the rate of reduction exceeded reoxidation by up to 2 times. Alkalinity fluxes were relatively smaller at the other sites, suggesting more complete oxidation of reduced species and/or the cooccurrence of aerobic respiration.

A predominant condition at many sites throughout the study was $\mathrm{TCO}_{2}: \mathrm{O}_{2}$ flux ratios of less than 1 coupled with alkalinity uptakes, indicating that either sulphide oxidation or nitrification may be significant influences on the benthic fluxes. Both reactions consume equal amounts of alkalinity and $\mathrm{O}_{2}$, thereby setting the lower limits of the $\mathrm{O}_{2}$ :alkalinity flux at -1 (Fig. 5). Furthermore, both sulphide-oxidising and nitrifying bacteria are predominantly chemoauto- 
trophic and may therefore be expected to lower the $\mathrm{TCO}_{2}: \mathrm{O}_{2}$ flux ratio via carbon fixation (Gunderson \& Mountain 1973). This was particularly apparent in the lower estuaries, where dark $\mathrm{TCO}_{2}$ uptakes coupled with alkalinity uptakes and oxidising sediment profiles (data not presented) suggested the likelihood of nitrification as a major influence. $\mathrm{O}_{2}$ production by BMA during the light, combined with high rates of bioturbation observed in the study systems, may have stimulated nitrification (Kemp et al. 1990, Risgaard-Petersen et al. 1994, Rysgaard et al. 1995), and nitrification may also be relatively more important during the dark when competition between nitrifying bacteria and BMA for $\mathrm{NH}_{4}^{+}$substrates is reduced (RisgaardPetersen et al. 1994). Sediment profiles in the upper and middle estuaries were more reducing, suggesting that the co-occurrence of small $\mathrm{TCO}_{2}: \mathrm{O}_{2}$ flux ratios (i.e. $<1)$ and alkalinity uptakes were more likely associated with sulphide/pyrite oxidations.

The wide range of $\mathrm{TCO}_{2}: \mathrm{O}_{2}$ flux ratios evident within sites throughout the study suggests that dark benthic metabolic processes are not in equilibrium and the redox reactions of carbon assimilation, mineralisation and reoxidation are dynamically phasing (Aller 1982). In many cases the balance between reduction and oxidation may occur over periods longer than the diurnal phase (e.g. days to weeks) depending on the nature of OM supply, therefore $24 \mathrm{~h}$ incubations may show an imbalance between $\mathrm{CO}_{2}$ and $\mathrm{O}_{2}$ fluxes. Benthic metabolism in the upper to middle Brunswick estuary is driven by large organic inputs of phytodetritus during algal blooms. During and immediately following the deposition of a pelagic phytoplankton bloom, rates of sulphate reduction may exceed the oxidation of sulphides (e.g. summer wet season) resulting in the net accumulation of reduced species. A reoxidation phase, stimulated by bioturbation (Aller 1982, Rysgaard et al. 2000), may then occur as the labile carbon supply begins to wane either with the onset of shorter days during winter or as the bloom becomes nutrient-limited (Ferguson et al. unpubl.), reducing the $\mathrm{TCO}_{2}: \mathrm{O}_{2}$ flux ratio to less than 1 . The SOD experiments suggested that benthic $\mathrm{O}_{2}$ fluxes may include a large component due to AOD/COD and that fluxes may be enhanced as a function of bioturbation. Similarly, high rates of bioturbation by deposit feeders such as Capitellid polychaetes have been shown to be important in the reoxidation of reduced sulphides (Chareopanich et al. 1993, 1994, Banta et al. 1999). Sediment reworking and bio-irrigation caused obvious zones of oxidation adjacent to polychaete burrows, suggesting that bioturbation may have been important in the oxidation of reduced species from deeper, reduced sediments and may therefore be an important influence on $\mathrm{TCO}_{2}: \mathrm{O}_{2}$ flux ratios.
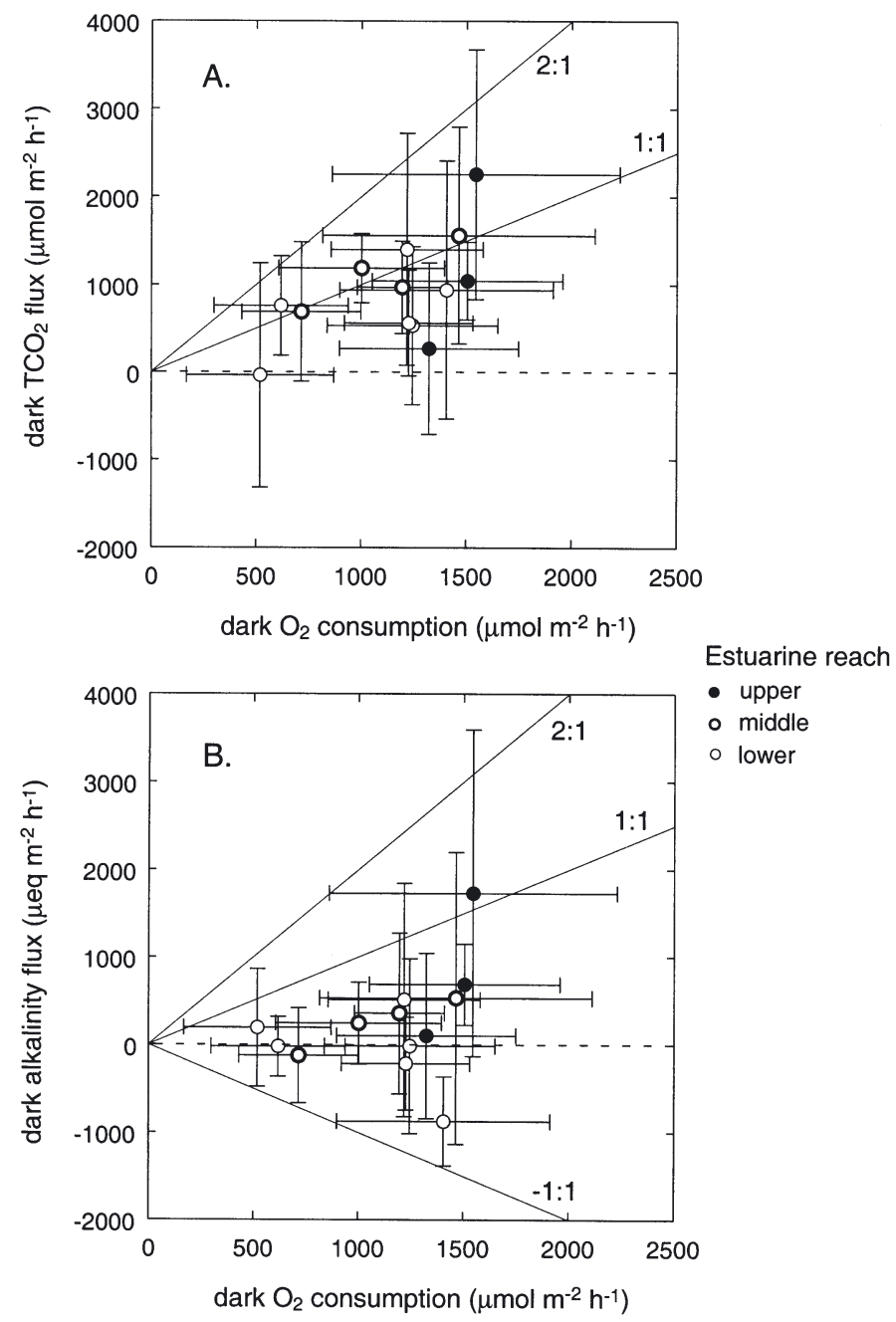

Fig. 5. (A) Relationships between dark $\mathrm{O}_{2}$ and $\mathrm{TCO}_{2}$ fluxes in the study estuaries. The region between $\mathrm{TCO}_{2}: \mathrm{O}_{2}$ ratio $=1$ and $\mathrm{TCO}_{2}: \mathrm{O}_{2}$ ratio $=2$ is the likely relationship expected for aerobic respiration with no, and maximum, $\mathrm{CaCO}_{3}$ dissolution, respectively. Fluxes due to anaerobic respiration may also fall within this region depending on the degree of reoxidation of reduced by-products occurring. (B) The relationship between dark $\mathrm{O}_{2}$ and alkalinity fluxes. $\mathrm{O}_{2}$ :alkalinity flux ratios of 1 may occur during aerobic respiration if maximum $\mathrm{CaCO}_{3}$ dissolution occurs. Ratios in excess of 1 indicate anaerobic respiration processes such as sulphate reduction. Error bars are SD $(\mathrm{n}=12)$

The average dark $\mathrm{TCO}_{2}: \mathrm{O}_{2}$ flux ratios (Table 3) balanced for most sites over the study period (i.e. $\mathrm{TCO}_{2}: \mathrm{O}_{2}$ was between the expected range of 0.75 and 2). The most significant departures were sites where the ratio fell below 0.5 , suggesting that the sulphide-oxidation phase or nitrification may be the more frequent condition. Obviously, the imbalance between $\mathrm{TCO}_{2}$ and $\mathrm{O}_{2}$ fluxes is not sustainable since even in the event of complete reoxidation of reduced species, fluxes should ultimately balance over the year. This suggests that the 
sampling frequency during the current study was insufficient to characterise benthic metabolic processes adequately. It is possible that the periods where anaerobic mineralisation exceeds reoxidation following large OM inputs (e.g. during the growth phase of pelagic phytoplankton blooms) may be relatively short-lived. The rate of OM mineralisation (and production of reduced species) is relatively high during these events and fuels a longer subsequent period of reoxidation as OM supply wanes. Thus, reoxidation periods may be the more dominant condition, and unless sampling strategies target and track specific events (e.g. floods or pelagic blooms) there will be a tendency for $\mathrm{O}_{2}$ fluxes to exceed $\mathrm{TCO}_{2}$ fluxes in benthic flux experiments.

\section{Benthic productivity}

There was a positive relationship (combined estuaries $\mathrm{r}^{2}=0.69, \mathrm{p}<0.0001$ ) between gross $\mathrm{O}_{2}$ production and $\mathrm{TCO}_{2}$ uptake, and a tighter relationship (combined estuaries $\mathrm{r}^{2}=0.82, \mathrm{p}<0.0001$ ) between net light $\mathrm{O}_{2}$ and $\mathrm{TCO}_{2}$ fluxes, suggesting that some error may be introduced by the assumptions used to calculate gross productivity (Fig. 6). Most points plot close to the 1:1 line (assuming ammonium as the nitrogen source) and the 1.38:1 line (assuming nitrate to be the nitrogen source). An additional 1:2 line has been added to account for the maximum $\mathrm{TCO}_{2}$ uptake assuming 1 mole of $\mathrm{CO}_{2}$ is consumed by $\mathrm{CaCO}_{3}$ precipitation for every mole of carbon fixed by autotrophic production (Eq. 7). The most significant error is likely to be the use of inappropriate respiration rates obtained from dark measurements. While light-enhanced respiration is known to occur in most autotrophs (Epping \& Jørgensen 1996, Falkowski \& Raven 1997), it is likely that this should affect both $\mathrm{O}_{2}$ and $\mathrm{TCO}_{2}$ fluxes equally. There may, however, be diel discrepancies between measured $\mathrm{O}_{2}$ and $\mathrm{TCO}_{2}$ fluxes due to $\mathrm{O}_{2}$-consuming processes such as sulphide oxidation and nitrification, and $\mathrm{CO}_{2}$ production by anaerobic processes such as sulphate reduction. Oscillation in benthic redox conditions caused by a reduction in $\mathrm{O}_{2}$ penetration towards the end of the night (Revsbech et al. 1980) may favour an increase in sulphate reduction rates resulting in a build-up of reduced species, which are subsequently oxidised during the day when photosynthetic oxygen production proceeds. This is supported by Weiland \& Kuhl (2000), who found that the zone of sulphide oxidation migrated towards the surface of cyanobacterial mats during the light. Nitrification would also be stimulated by increased oxygen production (RisgaardPetersen et al. 1994) resulting in a net drawdown on oxygen fluxes. These processes may then be further complicated by the occurrence of significant bioturba-
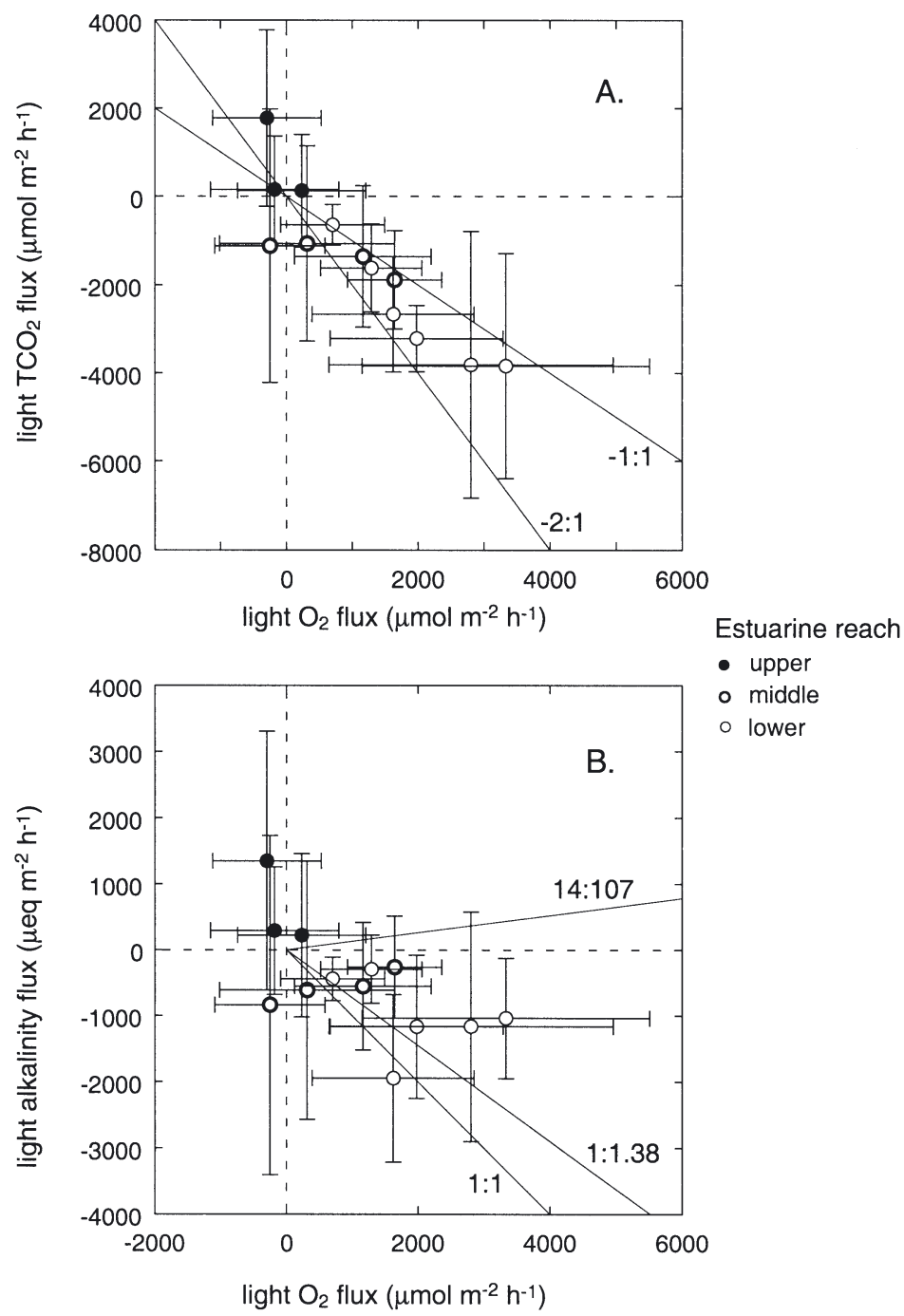

Fig. 6. (A) Relationships between net light $\mathrm{O}_{2}$ and $\mathrm{TCO}_{2}$ fluxes. The ranges given represent the expected relationships assuming $\mathrm{NO}_{3}^{-}$as the primary nitrogen source (-1:1.38), $\mathrm{NH}_{4}{ }^{+}$ $(-1: 1)$, and the presence of $\mathrm{CaCO}_{3}$ precipitation $(-2: 1)$. (B) Relationships between net light $\mathrm{O}_{2}$ and alkalinity fluxes. The ranges are as above: $\mathrm{NO}_{3}{ }^{-}(16: 107), \mathrm{NH}_{4}{ }^{+}(-14: 107)$, and $\mathrm{CaCO}_{3}$ precipitation $(-1: 1)$. Alkalinity uptakes in excess of $-1: 1$ are assumed to be due to either nitrification or sulphide oxidation. Error bars are SD $(\mathrm{n}=12)$

tion by meiofauna at all study sites, which may increase the extent of reoxidation in these surface sediment layers (Aller 1982).

As with dark fluxes, alkalinity can provide further insights into the likely diagenetic processes occurring during the light. Fig. 6B shows light alkalinity fluxes plotted as a function of net light $\mathrm{O}_{2}$ flux, with theoretical lines accounting for the reduction in alkalinity due to $\mathrm{NH}_{4}{ }^{+}$assimilation and $\mathrm{CaCO}_{3}$ precipitation. Assuming that $\mathrm{NH}_{4}{ }^{+}$is the nitrogen source used by benthic photoautotrophs, alkalinity would be reduced at a rate 
of 14 equivalents per 107 moles $\mathrm{O}_{2}$ produced (Eq. 1). Depletion of free $\mathrm{CO}_{2}$ by primary productivity (assumed here to occur at 1:1 with $\mathrm{O}_{2}$ production) causes a shift in the equilibria between participating carbonate species causing a precipitation of $\mathrm{CaCO}_{3}$, further decreasing alkalinity (Eq. 7) and releasing bicarbonate. The remaining alkalinity uptake can then be attributed to nitrification (Eq. 2), sulphide oxidation (Eq. 5) or pyrite oxidation (Eq. 4). Fig. 6B shows that, in most cases, alkalinity uptake is accounted for by $\mathrm{NH}_{4}{ }^{+}$ uptake or $\mathrm{CaCO}_{3}$ precipitation; however, at some sites in the lower and middle estuaries there is excess alkalinity uptake that may be due to either nitrification or sulphide oxidation.

Significant rates of nitrification and/or reduced sulphur oxidation have implications for the use of oxygen as a measure of benthic productivity. Due to the ease of measurement, $\mathrm{O}_{2}$ is a commonly used measure of net benthic community metabolism (Odum 1956, Hall \& Moll 1975); however, $\mathrm{O}_{2}$ fluxes may produce underestimations of benthic metabolic processes. The cooccurrence of $\mathrm{O}_{2}$-consuming autotrophic processes with $\mathrm{O}_{2}$-producing photo-autotrophic processes will lead to a decoupling of $\mathrm{TCO}_{2}$ and $\mathrm{O}_{2}$ fluxes away from the expected stoichiometry for primary production (Eq. 1). Oxygen demand resulting from sulphide/pyrite oxidation and nitrification in an essentially $\mathrm{O}_{2}$-limited environment such as sediments would lead to a net drawdown on (and hence underestimation of) $\mathrm{O}_{2}$ effluxes from benthic photo-autotrophic production. Increased $\mathrm{O}_{2}$ availability in the sediments may also form a positive feedback by stimulating populations of sulphide-oxidising and nitrifying bacteria and hence rates (Weiland \& Kuhl 2000). This indicates that $\mathrm{O}_{2}$ fluxes may commonly underestimate benthic photoautotrophic production in euphotic sediments.

\section{Net daily metabolism}

Net $24 \mathrm{~h}$ fluxes of both $\mathrm{O}_{2}$ and $\mathrm{TCO}_{2}$ integrate light and dark benthic processes, giving an indication of the net benthic community metabolism. Integrating over the $24 \mathrm{~h}$ diurnal period takes into account variation in both heterotrophic and autotrophic metabolism throughout the diurnal cycle. Thus there are no errors introduced via assumptions made in productivity calculations, such as extrapolations of dark respiration rates to the light, or the extrapolation of light rates measured during short-term incubations to the full photo-period. Errors may be more related to the containment effects of longer incubations (Ferguson et al. unpubl.). Net $24 \mathrm{~h}$ metabolism also tends to accentuate the decoupling of $\mathrm{TCO}_{2}$ and $\mathrm{O}_{2}$ fluxes by AOD/ COD due to reduced sulphur oxidation and nitrifica-

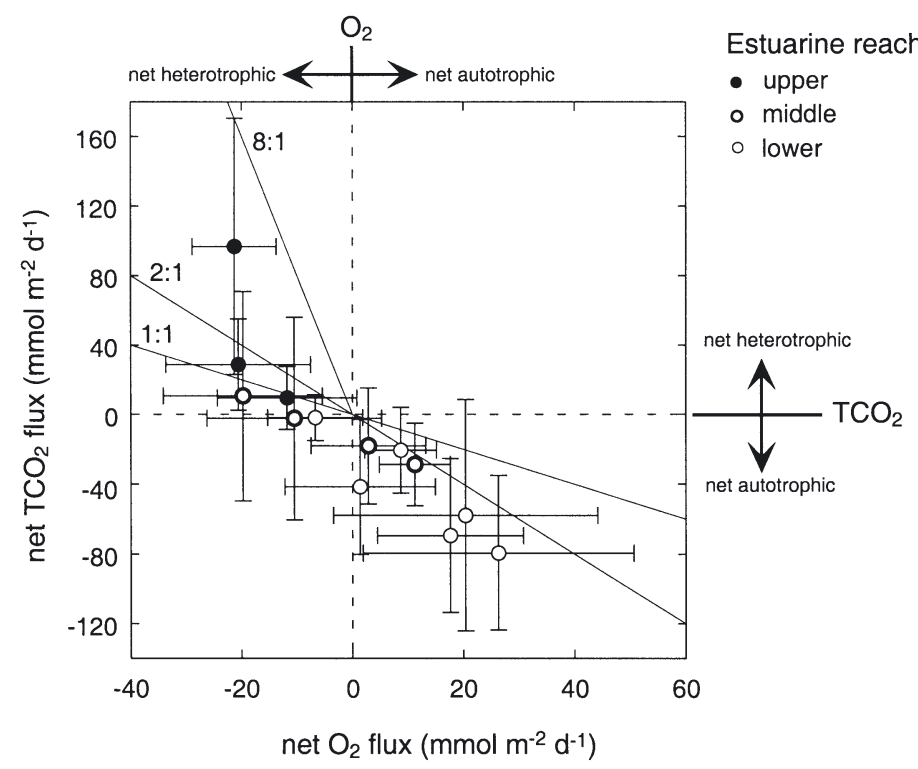

Fig. 7. Net diurnal fluxes of $\mathrm{O}_{2}$ and $\mathrm{TCO}_{2}$. The theoretical relationships between oxygen and carbon dioxide fluxes are shown in the presence of aerobic respiration/production alone (1:1) and coupled with $\mathrm{CaCO}_{3}$ dissolution/precipitation (2:1). Points plotting below the 1:1 and $-2: 1$ lines indicate the presence of significant rates of either nitrification and/or sulphide oxidation. Error bars are SD $(\mathrm{n}=12)$

tion. Thus, the categorisation of benthic communities as net heterotrophic or net autotrophic depends largely on which measure of metabolism is used $\left(\mathrm{O}_{2}\right.$ or $\left.\mathrm{TCO}_{2}\right)$. During this study, sites in the lower estuaries of all 3 systems displayed significant uptake of $\mathrm{TCO}_{2}$ but no net change of $\mathrm{O}_{2}$ over the $24 \mathrm{~h}$ incubation, resulting in high average $\mathrm{TCO}_{2}: \mathrm{CO}_{2}$ quotients for net $24 \mathrm{~h}$ fluxes (Fig. 7, Table 3). This suggests that chemoautotrophic pathways may be an important feature of benthic microbial ecology in these shallow systems. $\mathrm{O}_{2}$ fluxes can also underestimate heterotrophic activity in the upper estuaries due to anaerobic mineralisation by up to 6 fold (Fig. 7). The largest discrepancies occurred in the upper Brunswick estuary, where relatively large algal blooms (up to $60 \mathrm{\mu g} \mathrm{l}^{-1} \mathrm{chl}$ a) can occur rapidly during summer, resulting in the delivery of large amounts of phytodetritus to the sediments (Gay 2002, Ferguson et al. in press). Increased OM supply during algal blooms may potentially cause a shift in favour of microbial activity over metazoan activity (Malone \& Conley 1996) resulting in a relative decrease in bioturbation and hence reoxidation of reduced chemical species.

\section{LITERATURE CITED}

Aller RC (1982) The effects of macrobenthos on chemical properties of marine sediment and overlying water. In: McCall PL, Tevesz JS (eds) Animal sediment relations: the biogenic alteration of sediments. Plenum Press, New York, p 53-102 
Aller RC (1994) Bioturbation and remineralization of sedimentary organic matter: effects of redox oscillation. Chem Geol 114:331-345

Almgren T, Dryssen D, Fonselius S (1983) Determination of alkalinity and total carbonate. In: Grasshoff K, Ehrnhardt M, Kremling K (eds) Methods of seawater analysis. Verlag Chemie, Weinheim, p 99-123

Alongi DM (1998) Coastal ecosystem processes. CRC Press, Boca Raton, FL

Alongi DM, Tirendi F, Dixon P, Trott LA, Brunskill GL (1999) Mineralisation of organic matter in intertidal sediments of a tropical semi-enclosed delta. Estuar Coast Shelf Sci 48: 451-467

Anderson LG, Hall POJ, Iverfeldt A, Rutgers van der Loeff MM, Sundby I, Westerlund SFG (1986) Benthic respiration measured by total carbonate production. Limnol Oceanogr 31(2):319-329

Banta GT, Giblin AE, Hobbie JE, Tucker J (1995) Benthic respiration and nitrogen release in Buzzards Bay, Massachusetts. J Mar Res 53:107-135

Banta GT, Holmer M, Jensen MH, Kristensen E (1999) Effects of 2 polychaete worms, Nereis diversicolor and Arenicola marina, on aerobic and anaerobic decomposition in a sandy marine sediment. Aquat Microb Ecol 19:189-204

Barranguet C, Herman PMJ, Sinke JJ (1997) Microphytobenthos biomass and community composition studied by pigment biomarkers: importance and fate in the carbon cycle of a tidal flat. J Sea Res 38:59-70

Berelson W, Heggie D, Longmore A, Kilgore T, Nicholson G, Skyring G (1998) Benthic nutrient recycling in Port Phillip Bay, Australia. Estuar Coast Shelf Sci 46:917-934

Berg P, Risgaard-Petersen N, Rysgaard S (1998) Interpretation of measured concentration profiles in sediment porewater. Limnol Oceanogr 6:1500-1510

Bianchi TS, Findlay S, Fontvielle D (1991) Experimental degradation of plant materials in Hudson river sediments. Biogeochemistry 12:171-187

Billen G, Lancelot C (1988) Modelling benthic nitrogen cycling in temperate coastal ecosystems. In: Blackburn $\mathrm{TH}$, Sfrensen J (eds) Nitrogen cycling in coastal marine environments. John Wiley \& Sons, Chichester, p 341-378

Blackburn H (1995) The role and regulation of microbes in sediment nitrogen cycle. In: Joint I (ed) Molecular ecology of aquatic microbes. Springer-Verlag, Berlin, p 55-71

Blackburn TH, Henriksen K (1983) Nitrogen cycling in different types of sediments from Danish waters. Limnol Oceanogr 28:477-493

Blackburn TH, Hall POJ, Hulth S, Landen A (1996) Organic$\mathrm{N}$ loss by efflux and burial associated with a low efflux of inorganic $\mathrm{N}$ and with nitrate assimilation in Arctic sediments (Svalbard, Norway). Mar Ecol Prog Ser 141: 283-293

Boon AR, Duineveld GCA (1998) Chlorophyll a as a marker for bioturbation and carbon flux in southern and central North Sea sediments. Mar Ecol Prog Ser 162:33-43

Boon AR, Duineveld GCA, Kok A (1999) Benthic organic matter supply and metabolism at depositional and nondepositional areas in the North Sea. Estuar Coast Shelf Sci 49:747-761

Cadee GC, Hegeman J (1977) Distribution of primary production of the benthic microflora and accumulation of organic matter on a tidal flat area, Balgzand, Dutch Wadden Sea. Neth J Sea Res 11(1):24-41

Chareopanich C, Montani S, Tsutsumi H, Matsuoka S (1993) Modification of chemical characteristics of organically enriched sediment by Capitella sp. I. Mar Poll Bull 26(7): 375-379
Chareopanich C, Tsutsumi H, Montani S (1994) Efficiency of the decomposition of organic matter, loaded on the sediment, as a result of the biological activity of Capitella sp. I. Mar Poll Bull 28(5):314-318

Cherrier J, Bauer JE, Druffel ERM (1996) Utilisation and turnover of labile dissolved organic matter by bacterial heterotrophs in eastern North Pacific surface waters. Mar Ecol Prog Ser 139:267-279

Christensen PB, Nielsen LP, Sfrensen J, Revsbech NP (1990) Denitrification in nitrate-rich streams: diurnal and seasonal variation related to benthic oxygen metabolism. Limnol Oceanogr 35(3):640-651

Cifuentes LA, Coffin RB, Solorzano L, Cardenas W, Espinoza J, Twilley RR (1996) Isotopic and elemental variations of carbon and nitrogen in a mangrove estuary. Estuar Coast Shelf Sci 43:781-800

Cowan JLW, Boynton WR (1996) Sediment-water oxygen and nutrient exchanges along the longitudinal axis of Chesapeake Bay: seasonal patterns, controlling factors and ecological significance. Estuaries 19(3):562-580

D'Avanzo C, Kremer JN, Wainright SC (1996) Ecosystem production and respiration in response to eutrophication in shallow temperate estuaries. Mar Ecol Prog Ser 141: 263-274

Devol AH, Christensen JP (1993) Benthic fluxes and nitrogen cycling in sediments of the continental margin of the eastern North Pacific. J Mar Res 51:345-372

Epping EHG, Jørgensen BB (1996) Light-enhanced oxygen respiration in benthic phototrophic communities. Mar Ecol Prog Ser 139:193-203

Eyre BD (2000) Regional evaluation of nutrient transformation and phytoplankton growth in nine river-dominated subtropical east Australian estuaries. Mar Ecol Prog Ser 205: 61-83

Eyre BD, Ferguson AJP (2002) Comparison of carbon production and decomposition, benthic nutrient fluxes and denitrification in seagrass, phytoplankton, benthic microalgaeand macroalgae-dominated warm-temperate Australian lagoons. Mar Ecol Prog Ser 229:43-59

Falkowski PG, Raven JA (1997) Aquatic photosynthesis. Blackwell Science, Malden, MA

Ferguson AJP, Eyre BD, Gay JM (in press) Nutrient cycling in the sub-tropical Brunswick estuary, Australia. Estuaries

Gay JM (2002) Pelagic and benthic metabolism in three subtropical Australian estuaries. PhD thesis, Dept of Environmental Science and Management, Southern Cross University, Lismore

Gijs Kuenen J (1989) B. Colorless sulfur bacteria. In: Staley JT, Bryant MP, Pfenning N, Holt JG (eds) Bergy's manual of systematic bacteriology. Williams and Wilkins, Baltimore, p $1834-1837$

Gould DM, Gallagher ED (1990) Field measurement of specific growth rate, biomass and primary production of benthic diatoms of Savin Hill Cove, Boston. Limnol Oceanogr 35(8):1757-1770

Gunderson K, Mountain CW (1973) Oxygen utilisation and $\mathrm{pH}$ change in the ocean resulting from nitrate formation. Deep-Sea Res 20:1083-1091

Hall CAS, Moll R (1975) Methods for assessing aquatic primary productivity. In: Lieth $\mathrm{H}$, Whittaker $\mathrm{RH}$ (ede) Primary productivity in the biosphere. Springer-Verlag, New York, p 19-53

Hammond D, Fuller C, Harmon D, Hartman B and 6 others (1985) Benthic fluxes in San Francisco Bay. Hydrobiologia 129:69-90

Hammond DE, Giordani P, Berelson WM, Poletti R (1999) Diagenesis of carbon and nutrients and benthic exchange in 
sediments of the Northern Adriatic Sea. Mar Chem 66: 53-79

Henrichs SM, Doyle AP (1986) Decomposition of 14C-labeled organic substances in marine sediments. Limnol Oceanogr 31(4):765-778

Henriksen K, Kemp WM (1988) Nitrification in estuarine and coastal marine sediments. In: Blackburn TH, Sfrensen J (eds) Nitrogen cycling in coastal marine environments. John Wiley \& Sons, Chichester, p 207-249

Hopkinson CS, Giblin AE, Tucker J, Garrit RH (1999) Benthic metabolism and nutrient cycling along an estuarine salinity gradient. Estuaries 22(4):863-881

Jeffrey SW, Welschmeyer NA (1997) Spectrophotometric and fluorometric equations in common use in oceanography. In: Jeffrey SW, Mantoura RFC, Wright SW (eds) Phytoplankton pigments in oceanography: guidelines to modern methods. UNESCO, Paris, p 597-615

Joint IR, Morris RJ (1982) The role of bacteria in the turnover of organic matter in the sea. Oceanogr Mar Biol Annu Rev 20:65-118

Jørgensen BB (1996) Material flux in the sediment. In: Jørgensen BB, Richardson $\mathrm{K}$ (eds) Eutrophication in coastal marine ecosystems. American Geophysical Union, Washington, DC, p 115-135

Kemp WM, Sampou P, Caffrey J, Mayer M (1990) Ammonium recycling versus denitrification in Cheaspeake Bay sediments. Limnol Oceanogr 35(7):1545-1563

Kepkay PE, Jellet JF, Niven SEH (1997) Respiration and the carbon-to-nitrogen ratio of a phytoplankton bloom. Mar Ecol Prog Ser 150:249-261

Kerner M (1993) Coupling of microbial fermentation and respiration processes in an intertidal mudflat of the Elbe estuary. Limnol Oceanogr 38(2):314-330

Klump JV, Martens CS (1987) Biogeochemical cycling in an organic-rich coastal marine basin. 5. Sedimentary nitrogen and phosphorus budgets based upon kinetic models, mass balances, and the stoichiometry of nutrient regeneration. Geochim Cosmochim Acta 51:1161-1173

Koster M, Meyer-Reil LA (2001) Characterisation of carbon and microbial biomass pools in shallow water coastal sediments of the southern Baltic Sea (Nordrügensche Bodden). Mar Ecol Prog Ser 214:25-41

Kristensen E, Blackburn TH (1987) The fate of organic carbon and nitrogen in experimental marine sediment systems: influence of bioturbation and anoxia. J Mar Res 45: 231-257

Kristensen E, Jensen MH, Jensen KM (1997) Temporal variations in microbenthic metabolism and inorganic nitrogen fluxes in sandy and muddy sediments of a tidally dominated bay in the northern Wadden Sea. Helgol Meeresunters 51:295-320

Lancelot C, Billen G (1985) Carbon-nitrogen relationships in nutrient metabolism of coastal marine ecosystems. In: Jannasch HW, Williams Pl (eds) Advances in microbial ecology. Academic Press, London, p 263-321

Mackey MD, Mackey DJ, Higgins HW, Wright SW (1996) CHEMTAX-A programs for estimating class abundances from chemical markers: applications to HPLC measurements of phytoplankton. Mar Ecol Prog Ser 144:265-283

Malone TC, Conley DJ (1996) Trends in nutrient loading and eutrophication: a comparison of the Chesapeake Bay and the Hudson River estuarine systems. In: Sherman K, Jaworski NA, Smayda TJ (eds) The Northeast Shelf ecosystem: assessment, sustainability, and management. Blackwell Science, Cambridge, p 327-349

Meyer-Reil LA (1986) Measurement of hydrolytic activity and incorporation of dissolved organic substrates by microor- ganisms in marine sediments. Mar Ecol Prog Ser 31: 143-149

Meyer-Reil LA (1987) Seasonal and spatial distribution of extracellular enzymatic activities and microbial incorporation of dissolved organic substrates in marine sediments. Appl Environ Microb 53(8):1748-1755

Middleburg JJ, Klaver G, Nieuwenhuize J, Wielemaker A, de Haas W, Vlug T, van der Nat JFWA (1996) Organic matter mineralization in intertidal sediments along an estuarine gradient. Mar Ecol Prog Ser 132:157-168

Newell RC, Lucas MI, Linley EAS (1981) Rate of degradation and efficiency of conversion of phytoplankton debris by marine micro-organisms. Mar Ecol Prog Ser 6:123-136

Odum HT (1956) Primary production of flowing waters. Limnol Oceanogr 2:85-97

Overnell J, Edwards A, Grantham BE, Harvey SM, Jones KJ, Leftley JW, Smallman DJ (1995) Sediment-water column coupling and the fate of the spring phytoplankton bloom in Loch Linnhe, a Scottish fjordic sea-loch: sediment processes and sediment-water fluxes. Estuar Coast Shelf Sci 41:1-19

Parsons TR, Takahashi M, Hargrave B (1977) Biological oceanographic processes. Permagon Press, Oxford

Pedersen AGU, Bernsten J, Lomstein BA (1999) The effect of eelgrass decomposition on sediment carbon and nitrogen cycling: a controlled laboratory experiment. Limnol Oceanogr 44(8):1978-1992

Redfield AC (1934) On the proportions of organic derivatives in seawater-their relation to the composition of plankton. Liverpool University Press, Liverpool

Revsbech NP, Sfrensen J, Blackburn TH, Lomholt JP (1980) Distribution of oxygen in marine sediments measured with microelectrodes. Limnol Oceanogr 25(3):403-411

Rice DL (1982) The detritus nitrogen problem: new observations and perspectives from organic geochemistry. Mar Ecol Prog Ser 9:153-162

Richardson K, Jørgensen BB (1996) Eutrophication: definition, history and effects. In: Jørgensen BB, Richardson K (ed) Eutrophication in coastal marine ecosystems. American Geophysical Union, Washington, DC, p 1-19

Risgaard-Petersen N, Rysgaard S, Nielsen LP, Revsbech NP (1994) Diurnal variation of denitrification and nitrification in sediments colonised by benthic microphytes. Limnol Oceanogr 39(3):573-579

Rizzo WM, Christian RR (1996) Significance of subtidal sediments to heterotrophically-mediated oxygen and nutrient dynamics in a temperate estuary. Estuaries 19(2B): $475-487$

Rosenfield JK (1981) Nitrogen diagenesis in Long Island Sound sediments. Am J Sci 281:436-462

Rysgaard S, Christensen PB, Nielsen PL (1995) Seasonal variation in nitrification and denitrification in estuarine sediment colonised by benthic microalgae and bioturbating infauna. Mar Ecol Prog Ser 126:111-121

Rysgaard S, Thamdrup B, Risgaard-Petersen N, Fossing $\mathrm{H}_{4}$ Berg P, Christensen PB, Dalsgaard T (1998) Seasonal carbon and nutrient mineralisation in a high-Arctic coastal marine sediment, Young Sound, Northeast Greenland. Mar Ecol Prog Ser 175:261-276

Rysgaard S, Christensen PB, Sfrensen MV, Funch P, Berg P (2000) Marine meiofauna, carbon and nitrogen mineralisation in sandy and soft sediments of Disko Bay, West Greenland. Aquat Microb Ecol 21:59-71

Stumm W, Morgan JJ (1996) Aquatic chemistry: chemical equilibria and rates in natural waters. John Wiley \& Sons, New York, NY

Sun M, Aller RC, Lee C (1991) Early diagenesis of chloro- 
phyll-a in Long Island Sound sediments: a measure of carbon flux and particle reworking. J Mar Res 49:379-401 Sundback K (1986) What are the benthic microalgae doing on the bottom of Laholm Bay? Ophelia 4:273-286

Sundback K, Miles A (2000) Balance between denitrification and microalgal incorporation of nitrogen in microtidal sediments, NE Kattegat. Aquat Microb Ecol 22:291-300

Thamdrup B, Canfield DE (1996) Pathways of carbon oxidation in the continental margin sediments off Chile. Limnol Oceanogr 41(8):1629-1650

Twilley RR, Cowan J, Miller-Way T, Montagna PA, Mortazavi B (1999) Benthic nutrient fluxes in selected estuaries in the Gulf of Mexico. In: Bianchi TS, Pennock JR, Twilley RR (eds) Biogeochemistry of Gulf of Mexico estuaries. John Wiley \& Sons, New York, p 163-209

Editorial responsibility: Gary King,

Walpole, Maine, USA
Upton AC, Nedwell DB, Paarkes RJ, Harvey SM (1993) Seasonal benthic microbial activity in the southern North Sea; oxygen uptake and sulphate reduction. Mar Ecol Prog Ser 101:273-281

Valiela I (1995) Marine ecological processes. Springer-Verlag, New York

van Duyl FC, Kop AJ (1994) Bacterial production in North Sea sediments: clues to seasonal and spatial variations. Mar Biol 120:323-337

Weiland A, Kuhl M (2000) Short-term temperature effects on oxygen and sulfide cycling in a hypersaline cyanobacterial mat (Solar Lake, Egypt). Mar Ecol Prog Ser 196:87-102

Yoon WB, Benner R (1992) Denitrification and oxygen consumption in sediments of 2 south Texas estuaries. Mar Ecol Prog Ser 90:157-167

Submitted: May 1, 2002; Accepted: February 5, 2003

Proofs received from author(s): August 22, 2003 